\title{
Predicting the Impacts of Mississippi River Diversions and Sea-Level Rise on Spatial Patterns of Eastern Oyster Growth Rate and Production
}

Hongqing Wang ${ }^{1, *}$, Qin Chen ${ }^{2,3}$, Megan K. La Peyre ${ }^{4,5}$, Kelin $\mathrm{Hu}^{3}$, Jerome F. La Peyre ${ }^{5}$

${ }^{1}$ U. S. Geological Survey, Wetland and Aquatic Research Center, Baton Rouge, LA 70803, USA.

${ }^{2}$ Department of Civil and Environmental Engineering, Louisiana State University, Baton Rouge, LA 70803, USA.

${ }^{3}$ Center for Computation and Technology, Louisiana State University, Baton Rouge, LA 70803, USA.

${ }^{4}$ U.S. Geological Survey, Louisiana Cooperative Fish and Wildlife Research Unit, Baton Rouge, LA 70803, USA.

${ }^{5}$ School of Renewable Natural Resources, Louisiana State University Agricultural Center, Baton Rouge, LA 70803, USA.

* Corresponding author. Tel.: +1 225578 7482, Fax: +1 2255787927. E-mail address: wangh@usgs.gov (H. Wang). 


\section{ABSTRACT}

There remains much debate regarding the perceived tradeoffs of using freshwater and sediment diversions for coastal restoration in terms of balancing the need for wetland restoration versus preserving eastern oyster (Crassostrea virginica) production. Further complicating the issue, climate change-induced sea-level rise (SLR) and land subsidence are also expected to affect estuarine water quality. In this study, we developed a processbased numerical modeling system that couples hydrodynamic, water quality, and oyster population dynamics. We selected Breton Sound Estuary (BSE) $\left(\sim 2,740 \mathrm{~km}^{2}\right)$ in the eastern Mississippi River Deltaic Plain since it is home to several of the largest public oyster seed grounds and private leases for the Gulf coast. The coupled oyster population model was calibrated and validated against field observed oyster growth data. We predicted the responses of oyster population in BSE to small- $\left(142 \mathrm{~m}^{3} \mathrm{~s}^{-1}\right)$ and large-scale $\left(7,080 \mathrm{~m}^{3} \mathrm{~s}^{-1}\right)$ river diversions at the Caernarvon Freshwater Diversion structure planned in the 2012 Coastal Master Plan (Louisiana) under low $(0.38 \mathrm{~m})$ and high $(1.44 \mathrm{~m})$ relative sea-level rise (RSLR=eustatic SLR + subsidence) compared to a baseline condition (Year 2009). Model results showed that the large-scale diversion had a stronger negative impact on oyster population dynamics via freshening of the entire estuary, resulting in reduced oyster growth rate and production than RSLR. Under the large-scale diversion, areas with optimal oyster growth rates (>15 mg ash-free dry weight (AFDW) oyster $^{-1} \mathrm{wk}^{-1}$ ) and production (> $500 \mathrm{~g} \mathrm{AFDW} \mathrm{m}^{-2} \mathrm{yr}^{-1}$ ) would shift seaward to the southeastern edge of the estuary, turning the estuary into a very low oyster production system. RSLR however played a greater role than the small-scale diversion on the magnitude and spatial pattern of oyster growth rate and production. RSLR would result in an overall estuary-wide decrease in oyster growth rate and production as a consequence of decreased salinities in the middle and lower estuary because rising sea level likely causes increased stage and overbank flow downstream along the lower Mississippi River.

\section{Keywords:}

Eastern oyster, Growth rate and production, River Diversion, Hydrodynamics, Water quality, Sea-level rise 


\section{Introduction}

Large-scale riverine and estuarine restoration activities alter coastal habitats, often shifting dynamic water quality characteristics in relation to static habitats. This is particularly true along the northern Gulf of Mexico, where significant river management and restoration activities affect coastal estuarine water quality, potentially impacting the economically and ecologically important eastern oyster (Crassostrea virginica). Ecologically, oysters serve as ecosystem engineers, building reefs, providing habitat, filtering the water column, and reducing wave energies (Coen and Luckenbach, 2000; La Peyre et al., 2014). Economically, oyster production from the northern Gulf of Mexico represents over $50 \%$ of the nation's landings, and in coastal Louisiana, the oyster industry accounts for about $34 \%$ of the nation's landings (National Marine Fisheries Service (NMFS) landings data). Ensuring that this keystone species remains sustainable in the face of significant coastal restoration activities, high local subsidence rates and predicted sea level rise requires tools that can synthesize basic oyster population data with hydrodynamic and water quality information.

The complex interaction of numerous environmental factors affects the growth, reproduction, recruitment and survival of oyster populations. The impacts of water quality and hydrology on oyster production and growth are affected by multiple factors including water circulation, salinity, temperature, food, sedimentation, bottom type, disease, and predation (Shumway, 1996). Salinity and temperature are two key factors affecting oyster metabolism, while also impacting the likelihood of disease and predation on oyster populations (Shumway, 1996; La Peyre et al., 2010). Numerous studies have examined oyster growth and mortality explicitly in response to salinity, temperature, disease incidence and predation (Galtsoff, 1964; Dame, 1972; Shumway, 1996; Soniat et al., 1998; La Peyre et al., 2003; La Peyre et al., 2010; Banks, 2011; La Peyre et al., 2013). However, determining oyster population sustainability requires also considering other environmental factors, such as water circulation or movement, and water turbidity which can impact food availability and energy demands, and settlement patterns of oysters (Grizzle et al., 1992; Klinck et al., 1992; Powell et al., 1992; Lenihan et al., 1996; Soniat et al., 1998; Dekshenieks et al., 2000). 
In coastal Louisiana, and within one of the historically major oyster producing estuaries, Breton Sound Estuary, all of these environmental factors are being manipulated by coastal activities (Day et al., 2003; Meselhe et al., 2012; Couvillion et al., 2013), and affected by climate change including sea-level rise (SLR) and land subsidence (Williams, 2013). Coastal Louisiana is experiencing significant land loss, and as a result, has proposed large land-building activities, anchored by the use of sediment and river diversions (Peyronnin et al., 2013). Freshwater diversions can dramatically change estuarine salinity, temperature, suspended sediment concentration, chlorophyll- $\alpha$ concentration (Chl- $\alpha$ ) as well as water circulation and water level variability (Day et al., 2003; Lane et al., 2007; Snedden et al., 2007). Within the Breton Sound estuary, the Caernarvon Freshwater Diversion (CFD) has been in operation for numerous years, and studies have found that a spring pulse $\left(\sim 185 \mathrm{~m}^{3} \mathrm{~s}^{-1}\right)$ freshened and cooled the upper estuary for nearly one month, increasing Chl- $\alpha$ in the middle estuary (Day et al., 2003; Lane et al., 2007). While diversion discharge has to exceed $100 \mathrm{~m}^{3} \mathrm{~s}^{-1}$ for several weeks in order for river sediment to reach subsiding marsh regions for vertical accretion (Snedden et al., 2007), these long-duration pulses of one month or more in summer and when combined with heavy rainfall can depress oyster production, or result in significant oyster mortalities (Banks, 2011; La Peyre et al., 2013). At the same time, it is possible that diversions can be managed in ways that are beneficial to oysters. For example, freshwater diversions may lower salinities enough to reduce oyster predators or impacts from parasites (La Peyre et al., 2009), or, oysters may benefit from increased food supply, as indicated by elevated Chl- $\alpha$ levels (Lane et al., 2007).

Along with significant coastal restoration and management activities, recent predictions that global sea level will rise by $80-200 \mathrm{~cm}$ by 2100 (e.g., Pfeffer et al., 2008) suggest possible further impacts on estuarine water quality that may impact oyster populations. Relative sea level rise (RSLR= eustatic SLR + subsidence) can increase flooding levels, and also increase estuarine salinity (Hilton et al., 2008; Huang et al., 2015), a key factor affecting oyster growth and survival (Chatry et al., 1983; Shumway, 1996; Livingston et al., 2000; La Peyre et al., 2016). Changes in salinity regimes under RSLR would vary with locations in the estuary as a result of the variations in bathymetry, ocean circulation, and mixture between river water and tides (Hilton et al., 2008; Huang 
et al., 2015; Wang et al., 2016). Furthermore, it is unclear how RSLR effects would interact with coastal restoration plans which involve changes in river inputs into estuaries. Any future oyster management plan would not be accurate without considering the consequences of both RSLR and freshwater management activities.

Linking spatial and temporal changes in water quality to oyster growth rate and production requires coupling of hydrodynamic, sediment transport and water quality models with an oyster population model. While studies in BSE have demonstrated that CFD causes changes in the spatial and temporal patterns of temperature, salinity, total suspended solids (TSS), Chl- $\alpha$, and velocity with large pulses of water released during the springtime (Lane et al., 2007; Lundberg et al., 2014), the highly dynamic and variable water quality makes it difficult to fully capture all of the changes through discrete field sampling. As such, hydrodynamic, sediment transport and water quality modeling is required to fully capture such dynamic changes in space and time with sufficient spatial and temporal resolutions. Within BSE, hydrodynamic, sediment transport and water quality models have been coupled to examine the impacts of pulsed freshwater diversion on hydrology, water quality and sedimentation (e.g., Huang et al., 2011; Wang et al., 2016), and to investigate the hydrodynamic response of BSE to extreme events, such as Hurricanes Isaac (2012), Katrina (2005), and Gustav (2008) (Chen et al., 2010; Hu et al., 2015), or to predicted RSLR, but none have yet been coupled with any oyster population dynamic models. Oyster population models have been used to examine different management scenarios in Texas (Dekshenieks et al., 2000; Klink et al., 2002; Powell et al., 2003), and in Florida (Wang et al., 2008), but no oyster population model has been explicitly parameterized for coastal Louisiana, or coupled to existing Louisiana estuary water quality or hydrodynamic models.

In this study, our objectives were to 1) develop a high spatial resolution, processdriven, hydrodynamic, water quality, and oyster population coupled model; and, 2) project impacts of two levels of CFD (low, high) on oyster growth rate and production in BSE under different scenarios of RSLR. With a rapidly changing coastal environment, developing tools which can integrate and examine multiple future scenarios and linking them to fisheries outcomes are is critical. To our knowledge, there have been no such spatially explicit, process-driven, hydrodynamic, water quality and oyster population 
coupled models to address the consequences of combined freshwater management (e.g., freshwater diversion) and RSLR on the spatial and temporal oyster population dynamics (recruitment, growth and mortality) in the literature.

\section{Materials and methods}

\subsection{Study area}

The Breton Sound Estuary is a semi-enclosed estuary, bounded on the south and on the west by the levees of the Mississippi River, and on the north in part by the ridges of the Mississippi River Gulf Outlet (MRGO, closed in 2009) (Fig. 1). It is open to the Gulf of Mexico on the southeast. The estuary encompasses approximately $2,740 \mathrm{~km}^{2}$, of which $750 \mathrm{~km}^{2}$ are wetlands. The bathymetries in BSE are very complicated with numerous bays, lakes, bayous, canals and marshes. Astronomical tides in BSE are primarily diurnal with typical spring tide velocities of $10 \mathrm{~cm} \mathrm{~s}^{-1}$ (Cable et al., 2007). The estuary is a weakly stratified estuary with shallow water depth $(\sim 1.5 \mathrm{~m})$, and a larger tidal flux $\left(\sim 4,000 \mathrm{~m}^{3} \mathrm{~s}^{-1}\right)$ relative to average freshwater input $\left(\sim 40 \mathrm{~m}^{3} \mathrm{~s}^{-1}\right)$, and strong wind-induced mixing (Cable et al., 2007; Huang et al., 2011).The major vegetation types in the estuary along an increasing salinity gradient seaward are fresh, intermediate, brackish, and saline marshes (e.g., Sasser et al., 2008).

Oysters grow in abundance in the rich coastal waters of Louisiana and can be found naturally in dense aggregations called reefs both in the intertidal (nearshore) and subtidal environment, but primarily exist subtidally. The BSE is economically important because it is the home to several of the largest public oyster seed grounds and private leases for the Gulf coast (LDWF, 2009).

In 1992, the Caernarvon Freshwater Diversion (CFD) structure, located at the head of the BSE with the capability of delivering substantial freshwater, sediment and nutrient, became operational as a means to manage salinity for shellfish production in Breton Sound (U.S. Army Corps of Engineers, 1984). The original design capacity of the CFD was $225 \mathrm{~m}^{3} \mathrm{~s}^{-1}$. While originally conceived and designed to moderate salinities for shellfish production (U.S. Army Corps of Engineers, 1984), Louisiana's 2012 Master 
Plan identified CFD as one of the major tools to offset wetland loss (Couvillion et al., 2013).

\subsection{Modeling system}

We developed a process-based numerical modeling system that couples hydrodynamics, water quality, and oyster population dynamics to examine the impacts of a freshwater diversion and RSLR on oyster mortality, growth rate, and production. The coupled modeling system was based on the Delft3D model suite developed by Deltares (2013). The hydrodynamics in BSE were simulated using the Delft3D-FLOW model (Hu et al., 2015). The input includes tides, river discharge, atmospheric pressure, wind and waves, and outputs include water level, temperature and velocity field. The model has varying spatial resolutions with the finest resolution of $~ 20 \mathrm{~m}$ in BSE. The hydrodynamic model for BSE was calibrated and validated using observed water levels in 2009 as well as in the period of August 26-October 31, 2012 when Hurricane Isaac made landfall along coastal Louisiana on August 29, 2012 at multiple stations including those of the Louisiana Coastwide Reference Monitoring System (CRMS, http://lacoast.gov/crms2/). For details of the hydrodynamic model development, calibration, validation and application, refer to $\mathrm{Hu}$ et al. (2015).

We simulated the spatial and temporal patterns of salinity, TSS $\left(\mathrm{mg} \mathrm{l}^{-1}\right)$, and Chl- $\alpha(\mu \mathrm{g}$ $1^{-1}$ ) in BSE using the Delft3D-WAQ model (Wang et al., 2016). The Delft3D-WAQ model is based on the advection-diffusion-reaction equations, together with an extensive water quality library of inter-related source and sink terms to represent water quality processes. The Delft3D-WAQ is supplied with hydrodynamic data from the Delft3DFLOW model using the coupling procedure embedded in the Delft3D model suite. The biological processes in the model include algae growth, respiration and mortality due to natural mortality and zooplankton grazing, sedimentation and re-suspension of algae and particulate matter. Forcing functions for the Delft3D-WAQ model include freshwater flow, tidal exchange, water temperature, light, wind, and nutrients from the Caernarvon diversion and atmospheric deposition. The BSE water quality model was calibrated and validated using observed data in 2009 on salinity, TSS, and Chl- $\alpha$ at 16 water quality 
stations (Lane et al., 2007; Day et al., 2009; Lundberg et al., 2014) and 22 LDWF stations (LDWF unpublished data, Fig. 1). For details of the BSE water quality modeling, refer to Wang et al. (2016).

An oyster population model for Gulf of Mexico estuaries was applied to Louisiana oysters in this study. The oyster population model was first developed by Powell et al. (1992), Hofmann et al. (1992, 1994), and Klinck et al. (1992) for oyster dynamics in Galveston Bay, Texas. This oyster population model was further modified and applied to oyster population dynamics in Apalachicola Bay, Florida (Wang et al., 2008). The oyster population model has been applied to examine the effects of environmental changes including freshwater inflow on oyster population dynamics in estuaries along the Gulf of Mexico (Dekshenieks et al., 2000; Klinck et al., 2002; Wang et al., 2008). We applied the post-settlement population dynamic model with necessary modifications for the specific physical and biological conditions of BSE to simulate the growth, respiration, reproduction, and mortality of the benthic phase of the oysters' life history from newly settled juvenile through adulthood under various environmental conditions. The forcing functions of the model include estuary salinity, temperature, turbidity, food, and current velocity (Fig. 2). The details of the assumptions, main equations, relationships and parameters of the oyster population are described in Appendix A. The model parameters are given in Table 1.

Similar to Wang et al. (2008), three size classes (spat: $<25 \mathrm{~mm}$; seed: $\geq 25 \mathrm{~mm}, \leq 75 \mathrm{~mm}$ and sack: > $75 \mathrm{~mm}$ ) were used. Below we describe the modification of the oyster model compared to Wang et al. (2008) used for Louisiana oyster population.

The oyster length to biomass relationship was developed from data collected in previous oyster studies in BSE (La Peyre et al., 2013; Rybovich et al., 2016; La Peyre unpubl. data). The relationship can be described by the equation:

$L=6.23 W^{0.88}$ or $W=0.125 * L^{1.1357} \quad\left(p<0.05, \mathrm{R}^{2}=0.27, \mathrm{~N}=436\right)$ where $L$ is length $(\mathrm{cm})$ and $W$ is ash-free dry weight (AFDW, g).

The mortalities of oysters in BSE were estimated using the following equations based on long-term monitoring (1988-2012) data on seasonal mortality and average salinity and temperature at multiple stations in the estuary (La Peyre et al., 2016):

$M=0.45 S^{2}-10.59 S+1.46 T^{2}-65.28 T+794.64\left(p<0.05, \mathrm{R}^{2}=0.22\right)$ 
where $M$ is annual mean oyster mortality (\%), $S$ is annual mean salinity and $T$ is annual mean temperature. At all temperature regimes, $M=100 \%$ when salinity is $\leq 2$ (Galtsoff, 1964; La Peyre et al., 2009; Rybovich et al., 2016), $M=0.01 \%$ if $M \leq 0$, and $M=100 \%$ if $M>100 \%$. Furthermore, these mortality rates were applied to what we termed the spawning period (May-October) only based on field data indicating that the vast majority of mortality (>95\%) occurred during this time period (La Peyre et al., 2013; Rybovich et al., 2016) in BSE, and in other Gulf coast estuaries such as Apalachicola Bay, Florida (e.g., Petes et al., 2012). Because very few $(<5 \%)$ mortalities are reported during the November-April time period (Petes et al., 2012; La Peyre et al., 2013; Rybovich et al., 2016), we set mortality to zero for this time period in the model.

Food supply is affected by population density and current velocity (Klinck et al., 1992; Lenihan et al., 1996). Growth of juvenile eastern oysters increased with flow velocity up to $7 \mathrm{~cm} \mathrm{~s}^{-1}$ as a result of enhanced food concentration due to the enhancement of turbulent vertical mixing (Lenihan et al., 1996), but feeding was inhibited above $\sim 10 \mathrm{~cm} \mathrm{~s}^{-1}$ (Grizzle et al., 1992). The food reduction from population density and flow velocity is described by Eq. A.6 in Appendix A following Klinck et al. (1992). In Klinck et al. (1992), high flow and low flow tend to result in different food reduction indicated by the two sets of $k$ and $r$ values in the equation. In this study the values of $k$ and $r$ are determined by velocity threshold. The density on food reduction factor and the velocity threshold on food reduction factor were obtained via calibration. We also modified larval life span from 15 to 18 days based on observations for Louisiana oysters.

\subsection{Model set-up}

We selected Year 2009 as the baseline year for oyster simulations since sufficient field data on both oyster population characteristics and physical environmental conditions are available for the development of both the water quality and oyster models. Also, 2009 represented an average year, with the diversion discharge at CFD $\sim 53 \mathrm{~m}^{3} \mathrm{~s}^{-1}$, very close to the average of $\sim 57 \mathrm{~m}^{3} \mathrm{~s}^{-1}$ for the period of 2001-2012 measured by the USGS National Water Information System at Caernarvon Outfall Channel station (USGS 295124089542100). The oyster model was first tested, calibrated and validated in a non- 
spatial version using site-specific data at a daily time step. After the calibration and validation, the site-specific oyster model was converted to a spatial model to simulate spatial oyster dynamics under various scenarios of CFD diversion and RSLR in BSE.

The spatial oyster model was run at a regular grid cell size of $500 \mathrm{~m}$ by $500 \mathrm{~m}$ and a weekly time step that are sufficient for describing oyster population dynamics in BSE. Depth-averaged results from the Delft3D model on hydrodynamics and water quality were used to drive the BSE spatial oyster model since BSE is a shallow deltaic estuary (Cable et al., 2007; Snedden et al., 2007). Field measurements of surface and bottom salinity at oyster reefs conducted by LDWF also show that there is only small difference between surface and bottom salinities (data not shown). Higher spatial and temporal resolution hydrodynamic and water quality model results of spatial environmental conditions (salinity, temperature, TSS, Chl- $\alpha$ and current velocity) under various diversion, RSLR and the combined scenarios were aggregated into spatial data layers with a 500-m spatial resolution and a weekly temporal resolution as inputs into the spatially explicit oyster population model. We delineated oyster areas ( $<3 \mathrm{~m}$ water depth in sub-tidal zones) in BSE based on information on coverage of historical and current reefs, public seed grounds, and private lease areas from LDWF (Fig. 1).

\subsection{Model calibration and validation}

In this study, oyster growth rate is defined as the somatic production per individual oyster during a week (unit: mg AFDW oyster ${ }^{-1} \mathrm{wk}^{-1}$ ) and oyster production is determined by the accumulated biomass from all oysters over per unit area in a year (unit: g AFDW $\left.\mathrm{m}^{-2} \mathrm{yr}^{-1}\right)$. The BSE oyster model was calibrated for 2009 as oyster growth, mortality and environmental data were available. Daily salinity and temperature were taken from three USGS continuous data recorders located along a salinity gradient in BSE (Cow Bayou, USGS 073745258; Bay Gardene, USGS 07374527; and Snake Island, USGS 07374526). Daily values of TSS, and Chl- $\alpha$, and current velocity in 2009 were provided by the baseline year coupled hydrodynamic and water quality model (Wang et al., 2016). Chl- $\alpha$ was used as a surrogate of available food following Soniat et al. (1998): food $=0.088 \times$ Chl- $\alpha+0.520$. 
Initial values of population density (number of oysters per square meter) and spawning period (May to October) mortalities in 2009 for each of the three size classes were derived from the LDWF Stock Assessment (LDWF, 2009: mortality, density) and LDWF Nestier Data Tray (unpubl.: growth). Average biomass of each size class was derived from the length-biomass relationship (Eq. 1).

Model parameters for the calibration include assimilation efficiency, maximum reproduction efficiency, larval to spat survival rate, larvae mortality, and population density on food reduction factor (Table 1). The best estimates of the parameters were obtained when the closest agreement between simulation and observation on oyster growth rates (g AFDW per oyster) was reached. For field growth rates at each quarter, minimum, $1^{\text {st }}$ quarter, median, $3^{\text {rd }}$ quarter, and maximum value were calculated to indicate the variations in field biomass growth rates.

The oyster model was validated using oyster growth and mortality data in 2011 also at Cow Bayou, Bay Gardene, and Snake Island sites. Daily values of salinity and temperature in 2011 were obtained from the same three USGS recorders noted above. Daily values of TSS, Chl- $\alpha$, and current velocity in 2011 were provided by the coupled hydrodynamic and water quality model, in which observed MR discharge at Caernarvon in 2011 was incorporated with the boundary conditions in tide and salinity the same as the baseline year (2009). Bimonthly oyster growth (in length, and converted to biomass using the Length-Weight relationship, Eq. 1) and mortality data for 2011 were taken from La Peyre et al. (2013).

\subsection{Sensitivity analysis}

We conducted a formal sensitivity analysis of the oyster model to critical parameters listed in Table 1 . In the sensitivity analysis, parameters were decreased by $50 \%$ of the best estimates obtained through the calibration (varying one parameter at a time) following the protocol of Wang et al. (2012). The relative sensitivity index (RSI) of parameter $i$ to the state variable (i.e., oyster growth rate) was defined using the following equation:

$R S I=100 *\left(\frac{\Delta X / X}{\Delta P_{i} / P_{i}}\right)$ 
where $P_{i}$ is best estimate of parameter $i, \Delta P_{i}$ is the change in parameter $i, X$ is oyster growth rate at best estimate of parameter $i, \Delta X$ is the change in oyster growth rate due to the parameter $i$ change. The higher the RSI of a parameter, the more sensitive the model is to that parameter. Negative values of RSI indicate the negative relationship between parameter change and change in the state variable, oyster growth rate.

\subsection{Simulation scenarios}

We selected two diversion flow levels following what was laid out in the 2012 Master Plan (CPRA, 2012). Specifically, we modeled a low $\left(142 \mathrm{~m}^{3} \mathrm{~s}^{-1}\right)$ and a high $\left(7,080 \mathrm{~m}^{3} \mathrm{~s}^{-1}\right)$ flow scenario at the site of the Caernarvon Freshwater Diversion structure in the vicinity of Braithwaite, based on previously defined diversion levels (Wang et al., 2014). The low flow scenario involves continuous operation when MR flow exceeds 5,663 $\mathrm{m}^{3} \mathrm{~s}^{-1}$, and no operation (closed) below 5,663 $\mathrm{m}^{3} \mathrm{~s}^{-1}$. The high flow scenario, representing the high end of the designed diversion discharge in the 2012 Master Plan, involves full flow $(7,080$ $\mathrm{m}^{3} \mathrm{~s}^{-1}$ ) when MR flow exceeds $25,485 \mathrm{~m}^{3} \mathrm{~s}^{-1}$; operation at $1,416 \mathrm{~m}^{3} \mathrm{~s}^{-1}$ for MR flow from $25,485 \mathrm{~m}^{3} \mathrm{~s}^{-1}$ down to $16,990 \mathrm{~m}^{3} \mathrm{~s}^{-1}$, operation at $8 \%$ of river flow for MR flow from $16,990 \mathrm{~m}^{3} \mathrm{~s}^{-1}$ down to $5,663 \mathrm{~m}^{3} \mathrm{~s}^{-1}$, and no operation (closed) below 5,663 $\mathrm{m}^{3} \mathrm{~s}^{-1}$. In the lower MR, riverine flow for the range of stages is entirely constrained within the levees upriver right above Bohemia; below Bohemia, the river is mostly contained up to 20,000 $\mathrm{m}^{3} \mathrm{~s}^{-1}$; higher flows overtop the low eastern river bank into the lower BSE (Fig. 1) (Martyr et al., 2013). There were overbank flows south of Bohemia during May and November for all scenarios according to MR discharge in 2009 at Belle Chasse, Louisiana (USGS 07374525). Similarly, we chose two RSLR scenarios: low $=0.38 \mathrm{~m}$ and high $=1.44 \mathrm{~m}$, for BSE during the next 50 years based on predicted eustatic SLR rates (DeMarco et al., 2012) and land subsidence rates (Peyronnin et al., 2013) for coastal Louisiana. We ran the model using a full factorial model of all individual and combined diversion (low, high) and RSLR (low, high) scenarios, along with the baseline year (2009).

\section{Results}




\subsection{Model calibration and validation}

The oyster population model was calibrated using the 2009 growth data (converted from shell length to biomass) at Cow Bayou, Bay Gardene, and Snake Island sites (Fig. 1). The simulated mean oyster growth rates (mg AFDW per oyster during measurement periods) at the three sites were all within the observed ranges of growth rate (Fig. 3).

Specifically, all simulated growth rates with the exception of seed oysters during April to June and sack oysters during July to September at Snake Island were within the 25-75 percentiles of the observed values. Simulated growth rates for seed oysters at Cow Bayou appeared to be at the lower end of the observations ( $\left.20 \mathrm{mg} \mathrm{AFDW} \mathrm{oyster}^{-1}\right)$.

Validation results show that the oyster population model is capable of capturing oyster growth rates at oyster sites in BSE (Fig. 4). The value of $\mathrm{R}^{2}$ is $>0.7$ indicating that more than $70 \%$ of the observed variation in oyster growth rates in 2011 can be explained by the oyster model. The oyster population model tends to overestimate observed growth rates when physical environmental conditions are favorable but underestimate observed values when oysters were exposed to low salinities. With highly unfavorable conditions, it was possible for oyster growth rates to be negative due to the reductions in filtration, net growth, and reproduction as well as increased respiration. In fact, the model produced three negative biomass-based growth rates at Cow Bayou (March-April, and May-June) and Bay Gardene (September - October), and these rates were assigned zero in order to compare the length-converted observations.

\subsection{Sensitivity analysis}

At the total population level, the oyster model was mostly sensitive to assimilation efficiency, maximum reproduction efficiency, and the effects of population density on food reduction (Table 2). As expected, a reduction in assimilation efficiency resulted in a decrease of oyster growth rates whereas reductions in maximum reproduction efficiency and population density on food reduction factor led to increases in oyster growth rates. The total population level model sensitivity indicates that population intrinsic traits (e.g., 
assimilation efficiency, maximum reproduction efficiency, and population density on food reduction) dominate model performance.

The oyster model sensitivity to these parameters differed slightly when evaluated by size classes. At the seed level, although assimilation efficiency and maximum reproduction efficiency were still the top two parameters, velocity on food reduction threshold became the third critical model parameter (Table 2). For sack oysters, assimilation efficiency, population density on food reduction factor, and larvae mortality were the top three critical model parameters. Furthermore, the fraction of cumulative reproductive biomass and velocity on food reduction threshold affected differently the model performances. The reduction in fraction of cumulative reproductive biomass tended to increase growth rates of seed oysters but decrease that of sack oysters. In comparison, the reduction in velocity on food reduction threshold tended to increase growth rates of sack oysters while decreasing rates of seed oysters. Overall, sensitivity analysis suggests that parameters representing population intrinsic traits dominate model performance, but parameters reflecting the physical conditions such as current velocity are also critical in controlling oyster growth especially for seed oysters.

\subsection{Spatial patterns of oyster dynamics under the baseline condition}

Oyster growth rate and production in the baseline year (2009) had similar patterns with highest growth rates (> $15 \mathrm{mg}$ AFDW oyster ${ }^{-1} \mathrm{wk}^{-1}$ ) and production $\left(>300 \mathrm{~g} \mathrm{AFDW} \mathrm{m}^{-2}\right.$ $\mathrm{yr}^{-1}$ ) in the middle and lower estuary (Figs. 5a and 5b). The area with the highest simulated growth rate $\left(\sim 23 \mathrm{mg}\right.$ AFDW oyster $\left.{ }^{-1} \mathrm{wk}^{-1}\right)$ and production $\left(>500 \mathrm{~g} \mathrm{AFDW} \mathrm{m}^{-2}\right.$ $\mathrm{yr}^{-1}$ ) was located mid-estuary; lowest overall growth rates $\left(<5 \mathrm{mg}\right.$ AFDW oyster $\left.{ }^{-1} \mathrm{wk}^{-1}\right)$ and oyster production ( $<200 \mathrm{~g} \mathrm{AFDW} \mathrm{m}^{-2} \mathrm{yr}^{-1}$ ) occurred in the upper estuary, in fresher areas. Overall, simulated oyster growth rates in BSE in 2009 ranged from $<0$ to 22.58 mg AFDW oyster ${ }^{-1} \mathrm{wk}^{-1}$ (mean \pm standard deviation, SD: $4.10 \pm 3.15 \mathrm{mg}$ AFDW oyster ${ }^{-1}$ $\mathrm{wk}^{-1}$ ) and simulated oyster production ranged from 124 to $2,747 \mathrm{~g} \mathrm{AFDW} \mathrm{m}^{-2} \mathrm{yr}^{-1}$ (mean $\pm \mathrm{SD}: 303 \pm 150 \mathrm{~g} \mathrm{AFDW} \mathrm{m}^{-2} \mathrm{yr}^{-1}$ ).

\subsection{Impacts of River diversions on oyster growth rate and production}


The small-scale diversion $\left(142 \mathrm{~m}^{3} \mathrm{~s}^{-1}\right)$ scenario did not change the relative spatial patterns of growth and production across the estuary, but did result in decreased overall mean oyster growth rate $(\sim 19 \%)$ and production $(\sim 5 \%)$ (Table 3 , Figs. 6a and 7a). These overall mean reductions resulted from lowered growth rates and production in the optimal areas identified in the baseline year (Fig. 5a; middle and lower estuary). Specifically, the estuary-wide mean oyster growth rate was reduced to $3.33 \pm 2.92 \mathrm{mg}^{\text {AFDW oyster }}{ }^{-1} \mathrm{wk}^{-}$ ${ }^{1}$ from $4.10 \pm 3.15 \mathrm{mg}$ AFDW oyster ${ }^{-1} \mathrm{wk}^{-1}$ in the baseline condition (Table 3 ). This reduction was largely driven by a reduction in growth rates in the middle estuary (reduced by $\sim 10 \mathrm{mg}$ AFDW oyster ${ }^{-1} \mathrm{wk}^{-1}$ ). Similarly, the estuary-wide production decreased slightly from $303 \pm 150 \mathrm{~g}$ AFDW m$^{-2} \mathrm{yr}^{-1}$ in the baseline condition to $287 \pm$ $138 \mathrm{~g} \mathrm{AFDW} \mathrm{m}^{-2} \mathrm{yr}^{-1}$ under the small-scale diversion (Table 3).

In contrast, the large-scale diversion $\left(7,080 \mathrm{~m}^{3} \mathrm{~s}^{-1}\right)$ resulted in an overall mean negative growth rate and lowered production across most of the estuary, except for a small area at the most southern edge of the modeling extent, near Breton Island (Figs. 1, 6b, and 7b). The estuary-wide mean oyster growth rate was reduced from $4.10 \pm 3.15 \mathrm{mg}$ AFDW oyster ${ }^{-1} \mathrm{wk}^{-1}$ in the baseline condition to $-1.04 \pm 2.59 \mathrm{mg}$ AFDW oyster ${ }^{-1} \mathrm{wk}^{-1}$ under the large-scale diversion, a decrease of $\sim 125 \%$ (Table 3; Fig. 6b). A similar pattern occurred with oyster production with estuary-wide mean production decreasing from $303 \pm 150 \mathrm{~g}$ AFDW m $\mathrm{yr}^{-1}$ in the baseline condition to $121 \pm 100 \mathrm{~g} \mathrm{AFDW} \mathrm{m}^{-2} \mathrm{yr}^{-1}$ under the largescale diversion, a reduction of larger than $60 \%$ (Table 3). Similar to oyster growth rate patterns, the only remaining patches of high production (> $500 \mathrm{~g} \mathrm{AFDW} \mathrm{m}^{-2} \mathrm{yr}^{-1}$ ) shifted seaward near Breton Island (Table 3; Fig. 7b). Most of the estuary became nonproductive $\left(<200 \mathrm{~g} \mathrm{AFDW} \mathrm{m}^{-2} \mathrm{yr}^{-1}\right)$ with such areas covering over $1,442 \mathrm{~km}^{2}$ of the estuary under the large diversion, as opposed to only $320 \mathrm{~km}^{2}$ in the baseline condition, an increase of $350 \%$. Coincident with this increase in low production areas, was a significant decrease in high production areas (> $200 \mathrm{~g} \mathrm{AFDW} \mathrm{m}^{-2} \mathrm{yr}^{-1}$ ) which originally covered $\sim 1,300 \mathrm{~km}^{2}$, but now only covered $\sim 180 \mathrm{~km}^{2}$, a reduction of $86 \%$. The highest simulated production was 1,019 $\mathrm{g} \mathrm{AFDW} \mathrm{m}^{-2} \mathrm{yr}^{-1}$ under the large diversion compared to 2,747 $\mathrm{g} \mathrm{AFDW} \mathrm{m}^{-2} \mathrm{yr}^{-1}$ under the baseline condition (Table 3). 


\subsection{Impacts of RSLR on oyster growth rate and production}

Both low (0.38) and high (1.44) RSLR scenarios resulted in net decreases in estuarywide growth rate and production (Table 3; Figs. 6c, 6d, 7c, and 7d). Specifically, under the low RSLR scenario, growth rate was reduced to $2.68 \pm 2.92 \mathrm{mg}$ AFDW oyster ${ }^{-1} \mathrm{wk}^{-1}$ ( $\sim 35 \%$ compared to baseline; Table 3 ) and production reduced to $254 \pm 114 \mathrm{~g} \mathrm{AFDW} \mathrm{m}^{-2}$ $\operatorname{yr}^{-1}(\sim 16 \%$; Table 3$)$. Despite this overall reduction, some areas of the estuary resulted in significantly increased oyster growth rate, such as near Empire (Fig. 1) where growth rates increased as much as $28 \mathrm{mg}$ AFDW oyster ${ }^{-1} \mathrm{wk}^{-1}$ compared to the baseline condition (Figs. 5a and 6c). For production, the areas with production $>500 \mathrm{~g} \mathrm{AFDW} \mathrm{m}^{-2}$ $\mathrm{yr}^{-1}$ shrunk slightly but maintained a similar pattern as that in the baseline condition under low RSLR (Fig. 7c).

Under the high RSLR scenario, patches with highest growth rate (> $15 \mathrm{mg}$ AFDW oyster ${ }^{-1} \mathrm{wk}^{-1}$ ) and production (> $500 \mathrm{~g}^{\mathrm{AFDW} \mathrm{m}} \mathrm{m}^{-2} \mathrm{yr}^{-1}$ ) shifted from the middle estuary in the northeast near the MRGO to the southwestern portion of the estuary near the Bohemia-Empire region (Figs. 1, 6d). Despite these areas of high growth, the estuarywide growth rate decreased to $0.82 \pm 3.45 \mathrm{mg}$ AFDW oyster ${ }^{-1} \mathrm{wk}^{-1}(\sim 80 \%$ reduction; Table 3). Mean production also was reduced, decreasing to $192 \pm 92 \mathrm{~g} \mathrm{AFDW} \mathrm{m}^{-2} \mathrm{yr}^{-1}$ ( $36 \%$ reduction from baseline; Table 3). Both RSLR scenarios indicate that rising sealevel could increase oyster growth rate and production in areas of the estuary with historically low salinity whereas it decreases growth rate and production in areas of the estuary with historically moderate to high salinity; but results overall in a net estuary decrease in oyster growth rate and production.

\subsection{Combined impacts of river diversion and RSLR on oyster growth rate and production}

In all four combined cases, the simulated estuary-wide mean oyster growth rate and production decreased when RSLR scenarios $(0.38 \mathrm{~m}$ and $1.44 \mathrm{~m})$ were superimposed on each river diversion scenario (Figs. 6e-h, 7e-h; Table 3). The combined high diversion and high RSLR scenario resulted in the most negative impacts on both growth rate and production with negative growth ( $144 \%$ reduction from baseline), and production levels 
less than $33 \%$ of the baseline conditions (Table 3). The estuary-wide mean growth rates were reduced by $124 \%$ and $143 \%$ under the large diversion $\left(7,080 \mathrm{~m}^{3} \mathrm{~s}^{-1}\right)$ with RSLR rates of $0.38 \mathrm{~m}$ and $1.44 \mathrm{~m}$, respectively, compared to that in the baseline condition (Table 3). In contrast, under the small-scale diversion $\left(142 \mathrm{~m}^{3} \mathrm{~s}^{-1}\right)$, the estuary-wide mean growth rates were reduced by $54 \%$ and $74 \%$ with RSLR rates of $0.38 \mathrm{~m}$ and $1.44 \mathrm{~m}$, respectively (Table 3). The large-scale diversion had a greater impact than RSLR whereas RSLR played a greater role than the small-scale diversion on oyster growth rate.

Patterns were similar for production. Specifically, under the combination of smallscale diversion $\left(142 \mathrm{~m}^{3} \mathrm{~s}^{-1}\right)$ and low $\operatorname{RSLR}(0.38 \mathrm{~m})$, patches with high production $(>500$ $\mathrm{g} \mathrm{AFDW} \mathrm{m}^{-2} \mathrm{yr}^{-1}$ ) were still distributed in the middle and lower estuary near MRGO as that in the baseline condition (Figs. 5b and 7e) although the estuary-wide mean production decreased to $220 \pm 107 \mathrm{~g}$ AFDW m$^{-2} \mathrm{yr}^{-1}$ ( 27\% of reduction) (Table 3$)$. The patches with production $>500 \mathrm{~g}_{\text {AFDW m}}^{-2} \mathrm{yr}^{-1}$ shifted to the lower estuary near the Bohemia-Empire region under the small-scale diversion but the high RSLR scenario (Fig. $7 \mathrm{~g})$. Under the large-scale diversion, patches with high oyster production would disappear regardless of rates of RSLR (Figs. 7f and 7h). The estuary-wide mean production decreased to $\sim 110 \mathrm{~g} \mathrm{AFDW} \mathrm{m}^{-2} \mathrm{yr}^{-1}$ under the two RSLR scenarios compared to that in the baseline condition, a reduction of $>60 \%$ (Table 3), indicating that the estuary could become a very low oyster productive system under the large-scale diversion and high RSLR. Similarly, the large diversion had a greater impact than RSLR whereas RSLR played a greater role than the small-scale diversion on oyster production. Under the small-scale diversion $\left(142 \mathrm{~m}^{3} \mathrm{~s}^{-1}\right)$, the estuary-wide mean productions were reduced by $27 \%$ and $33 \%$ with RSLR rates of $0.38 \mathrm{~m}$ and $1.44 \mathrm{~m}$, respectively (Table 3 ).

\section{Discussion}

Development of a coupled hydrodynamic-water quality-oyster population level model provides a critical tool to inform management of oysters, and coastal restoration activities. The use of large-scale sediment diversions to protect coastal regions in Louisiana can be evaluated with this tool. In the case of Breton Sound Estuary, a mega-diversion would have significant and detrimental effects on oyster growth and production regardless of RSLR rates. In contrast, small scale diversions may shift areas of production, while 
RSLR impacts may become more important. In all cases, changes in salinity resulting from the diversions or RSLR (refer to Fig. 9 in Wang et al., 2016) seem to drive the response, although changes in TSS and Chl- $\alpha$ (proxy for food that is calculated from Chl$\alpha$ measurement using the equation of Soniat et al. 1998) also drive impacts on predicted oyster growth and population.

\subsection{Large-scale diversion impacts}

A large-scale diversion would have significant and detrimental effects on oyster growth and production within BSE. Only a small area would maintain positive growth rates, and this would be at the southern edge of the extent of the model, suggesting that BSE will no longer be a productive estuary for the oyster fishery. This detrimental effect is primarily attributed to the dramatic salinity change as a result of the freshening of the entire estuary through Caernarvon diversion and associated MR overbank inflow over the lower BSE (e.g., Martyr et al., 2013).

The large-scale diversion scenario resulted in a reduction of estuary-wide mean annual salinity from $11.7 \mathrm{ppt}$ to $3.5 \mathrm{ppt}$ (Wang et al., 2016) and high oyster mortalities (40 $100 \%$ ) across the estuary. These results match field data showing $100 \%$ oyster mortality in Cow Bayou near Bohemia (Fig. 1) during June-July (2010), which is attributed to extremely low salinity $(<2 \mathrm{ppt}$ ) from heavy rainfall combined with a prolonged nearly mid-size freshwater diversion $\left(250 \mathrm{~m}^{3} \mathrm{~s}^{-1}\right)$ ( La Peyre et al., 2013). In addition to salinity changes, the estuary-wide mean TSS increased by $>70 \%\left(\sim 17-20 \mathrm{mg} \mathrm{l}^{-1}\right)$ and mean Chl- $\alpha$ decreased by $>65 \%\left(\sim 9 \mu \mathrm{g}^{-1}\right)$ with the large-scale diversion. Increased TSS and decreased Chl- $\alpha$ would reduce oyster filtration and food ingestion, thereby reducing growth rate and production (e.g., Klinck et al., 1992; Powell et al., 1992; Shumway, 1996; Dekshenieks et al., 2000).

\subsection{Small-scale diversion impacts}

Model results show that a small-scale diversion would have less effect on oyster growth rate and production within BSE. The magnitude and distribution of optimal 
growth rate and production in BSE are slightly affected by the small-scale diversion (142 $\mathrm{m}^{3} \mathrm{~s}^{-1}$ ) at Caernarvon. The growth rate and production in the middle and lower estuary can be maintained, increased, or slightly reduced compared to that in the baseline condition depending on the locations in the estuary. For oysters near the freshwater sources (e.g., the Caernarvon diversion) where already lower salinities exist, increasing freshwater flow will result in reduced growth rate and oyster production whereas for oysters far away from freshwater sources with higher than optimal salinities, freshening will result in increased growth rate and production. If estuarine salinity is still in the optimal range (15-20 ppt from this study and La Peyre et al., 2016) for oyster growth under river diversions, then oyster growth and production can be sustained. The inflow from the small CFD diversion at the north of the estuary barely reached the middle and lower BSE (Fig. 1), thus having little influence on salinity over the oyster areas (private leases, reefs, and public seed grounds). Under the small-scale diversion $\left(142 \mathrm{~m}^{3} \mathrm{~s}^{-1}\right)$, the estuary-wide mean annual salinity over the oyster areas was slightly reduced to $9.6 \mathrm{ppt}$ from $\sim 11.7$ ppt. Indeed, existing CFD diversions (normally $<200 \mathrm{~m}^{3} \mathrm{~s}^{-1}$, classified as small-scale diversions) were found to have minimal impact on water quality including salinity, TSS and Chl- $\alpha$ in the oyster areas (Lane et al., 2007; Snedden et al., 2007), and no changes in spatial patterns of oyster production were found to relate to river inflow through CFD (Sable and Villarrubia, 2011).

\subsection{Diversion impacts under relative sea-level rise}

Rising sea level rates alone (low, high) and with the two diversions showed reduction of estuary-wide growth rate and production (Table 3) due mainly to a decreased salinity in the middle and lower estuary. Compared to the baseline condition, salinities in most areas of BSE were found to decrease under RSLR (Wang et al., 2016), which is opposite to the expectation of salinity increase with salt water intrusion under RSLR (e.g., Huang et al., 2015). However, previous studies using long-term monitoring data also showed that inflow from the lower MR (via overbank flooding) plays a more important role than tide on estuary salinity (e.g., La Peyre et al., 2016). Raising sea level could possibly be increasing the MR stage (Driessen and Ledden, 2013), result in higher inflow into the 
areas over the oyster reefs and public seed grounds via increased MR overbank flow, thereby reducing salinities in the middle and lower estuary. In contrast, in the areas with salinities < 5 ppt, near CFD and lower MR (e.g., near Empire), salinity could increase as high as 11.7 ppt under high RSLR (Wang et al., 2016), turning salinity from unsuitable to suitable for oyster growth. Changes in the spatial patterns of other water quality parameters due to rising sea level also contributed to changes in spatial patterns of oyster growth and production in BSE. Increases in TSS due to RSLR indicate increased sedimentation, which affect oyster recruitment and growth (e.g., Hofmann et al., 1994). Increased sedimentation and potential with high TSS due to re-suspension can result in not only reduced food filtration but also loss of available substrate for spat settlement (Solomon et al. 2014).

\subsection{Coastal management implication}

Results of this and previous studies (e.g., La Peyre et al., 2013; Soniat et al., 2013) related to freshwater and sediment diversions pose a great challenge to coastal restoration and resource management using Mississippi River diversions. On one hand, the mitigation of coastal wetland loss requires large-scale river diversions $\left(>1,416 \mathrm{~m}^{3} \mathrm{~s}^{-1}\right)$ to deliver a large amount of sediment to the sediment-starved hydrologic basins for building wetlands (filling the subaqueous portion before aerial expression) and vertical accretion to keep pace with RSLR (Allison and Meselhe, 2010; Day et al., 2013; Wang et al., 2014). Wang et al. (2014) determined that the large-scale diversion of $7,080 \mathrm{~m}^{3} \mathrm{~s}^{-1}$ in BSE could produce the maximum basin-wide vertical accretion and elevation gain whereas the small-scale diversion of $142 \mathrm{~m}^{3} \mathrm{~s}^{-1}$ only slightly increases vertical accretion thus having little contribution to wetland stability in the face of RSLR. On the other hand, large-scale sediment diversions will also cause a substantial amount of freshwater inflow to wetlands and downstream estuaries leading to dramatic changes in water quality (Wang et al., 2016) that in turn could negatively impact recruitment, growth and survival of fishery species as demonstrated by this study and other studies (e.g., La Peyre et al., 2013; Soniat et al., 2013). The ideal discharge rates for coastal wetland restoration versus management of oyster and other fishery species appear to be incompatible, and 
unfortunately, damages to oyster fishery by large-scale diversions for restoring coastal wetlands seem inevitable.

There are three critical considerations for ecosystem-based application of river diversions as a coastal restoration technique based on the simulation results of this study. Firstly, a comprehensive assessment of diversions with multiple goals of ecosystem benefits is needed for design and implication of large-scale freshwater and sediment diversions. The goals of diversions for improving water quality and habitat suitability of fishery species should be given adequate priority weights. Other impacts of river diversions on ecosystem services such as carbon sequestration and nitrogen denitrification and other biogeochemical cycles should also be included in the assessment of the multiple diversion goals (DeLaune and White, 2012; Rivera-Monroy et al., 2013).

Secondly, diversions should be managed to maximize the sediment supply, delivery and deposition onto the receiving wetlands while minimizing the damage to water quality and fishery production. For example, new techniques of capturing sediment as much as possible from diversions along the river bank or obtaining the maximum sediment/water ratio from river diversion structure (e.g., Meselhe et al., 2012; Meselhe et al., 2016) should be applied. Indeed, diversions could be operated to release large amounts of water and sediment in spring time when temperature is low to prevent high oyster mortality (Day et al., 2009; La Peyre et al., 2009, 2010; La Peyre et al., 2013

Thirdly, if restoring wetlands (land-building and vertical accretion) has to be the first priority of river diversions, then tremendous efforts have to be taken to relocate public seed grounds and private leases far away from BSE to the Gulf of Mexico. Some new oyster farming techniques have to be explored and applied. For example, off-bottom oyster farming allows oysters to grow in cages that are kept above seafloor and placed in food-rich waters for faster growth and increased survival by providing protection from predators and sediment burial (Walton et al., 2013; Leonhardt et al., 2017 ).

\subsection{Future research for model improvements}

The movement of larvae among grid cells is not simulated in the study. Larval growth and mortality during the planktonic larval phase are critical for oyster population 
dynamics (e.g., Dekshenieks et al., 2000). Inclusion of a larval model in the coupled hydrodynamics and oyster model is needed for Louisiana oyster model improvement.

In this study, we used a mortality model (Eq. 2) for all three size classes of oysters. It was found that mortality varies with different sizes of oysters and young oysters tend to have a higher mortality due to predation, but a low mortality caused by low salinity from freshwater inflow (e.g., La Peyre et al., 2013; Rybovich et al., 2016). In addition, zero mortality in early spring (e.g., March and April) was assumed in this study, but climate change and coastal restoration may lead to large MR diversion during early spring resulting in high oyster mortalities during that time period. However, limited field and laboratory data on mortalities of different size classes prevent the establishment of sizevarying mortalities as a function of multiple environmental factors. Therefore, further studies on mortality by size classes, by season, and by other physical factors should be explored. Furthermore, more data on the biomass measurements on oysters of all three size classes collected from sites well-distributed across BSE and over time are needed in order to increase the power of the length-biomass relationship.

Sensitivity analyses indicate that assimilation efficiency, maximum reproduction efficiency, population density on food reduction, and velocity on food reduction threshold are major model parameters that greatly determine model performance. In this study, best estimates of these parameters came from calibration. Further field studies are needed in order to not only reduce the model uncertainty, but also help to understand the mechanisms (internal and external controlling factors) of oyster growth, respiration, and reproduction in BSE.

Additionally, bottom substrates of oyster reefs, whether made of hard oyster shell or of alternative materials such as limestone play an important role on larval settlement, recruitment, growth and survival of juvenile and adult oysters (e.g., Soniat et al., 2013; La Peyre et al., 2014), but were not incorporated in this study, therefore, influences of the quality of reef substrates should be taken into account in prediction of future oyster population dynamics especially under various restoration activities.

\section{Conclusion}


A process-based spatially explicit hydrodynamic-water quality-oyster population coupled modeling system has been developed and was used to examine the impacts of Mississippi River diversions and relative sea-level rise on oyster growth rate and production in Breton Sound Estuary, Louisiana, the home to several of the largest public oyster seed grounds and private leases for the Gulf coast. Essentially, a large-scale river diversion would make the estuary non-productive $\left(<200 \mathrm{~g} \mathrm{AFDW} \mathrm{m}^{-2} \mathrm{yr}^{-1}\right)$, through a significant lowering of salinity, increase of TSS, and decrease in Chl- $\alpha$. In contrast, a small-scale diversion would have less effect on oyster growth and production within BSE, and suggests the growth rate and production in the middle and lower estuary can be minimally impacted. RSLR was only found to be relevant under the small diversion; however results were counterintuitive, with RSLR decreasing salinity, likely through impacts on MR inflow increases from SLR impacts on MR stages. Model sensitivity analysis suggests that parameters representing population intrinsic traits dominate model performance, but parameters reflecting the physical conditions such as current velocity are also critical in controlling oyster growth especially for seed oysters. It is a great challenge to coastal managers to use river diversions for simultaneously restoring wetlands and sustaining oyster production. A comprehensive assessment of diversions with multiple goals of ecosystem benefits is needed for design and implication of future large-scale sediment diversions. River diversions should be managed to maximize the sediment supply, delivery and deposition onto the receiving wetlands while minimizing the damage to water quality and fishery production.

\section{Acknowledgements}

The study was supported by the U.S. National Oceanic and Atmospheric Administration (NOAA) through Louisiana Sea Grant (grant R/OA-15) and by the U.S. Geological Survey (USGS) Ecosystem Mission Program. We would like to thank Patrick Bank and LDWF for oyster biological data. We are grateful to Tom Soniat and two anonymous reviewers for their constructive reviews of an earlier draft of this report. Any use of trade, firm, or product names is for descriptive purposes only and does not imply endorsement by the U.S. Government. 


\section{Appendix A. The oyster population model}

The oyster model is based on a standard energy flow equation in which net production $\left(N P_{j}\right)$ is calculated from the difference between assimilation $\left(A_{j}\right)$ and respiration $\left(R_{j}\right)$ and where net production is the sum of somatic $\left(P_{g j}\right)$ and reproductive tissue $\left(P_{r j}\right)$ production (Powell et al., 1992; Hofmann et al., 1992, 1994; and Klinck et al., 1992). The governing equation is

$N P_{j}=P_{g j}+P_{r j}=A_{j}-R_{j}$

where $j$ is size class. The equation for each oyster size class can be written as $\frac{d o_{j}}{d t}=P_{g j}+P_{r j}+($ gain from $j-1)-($ loss to $j+1)+($ gain from $j+1)-$ (loss from $j-1)-$ mortality

The model permits positive scope for growth, the accumulation of biomass as a result of ample food supply and favorable environmental conditions as well as negative scope for growth and the loss of biomass within size classes during the period of unfavorable environmental conditions.

(1) Feeding and assimilation

$$
F R=\frac{L^{0.96} T^{0.95}}{2.95}
$$

where $F R$ is the filtration rate ( $\mathrm{ml}$ filtered per individual per min); $L$ is the length $(\mathrm{cm})$, obtained from the length-biomass relationship (Eq. 1), the ash-free dry weight (g); and $T$ is the temperature in ${ }^{\circ} \mathrm{C}$.

(2) Filtration rate and salinity

Filtration rate is further modified by salinity:

$$
F R_{S}=\left\{\begin{aligned}
F R & \text { at } S \geq 7.5 p p t \\
\frac{F R(S-3.5)}{4.0} & \text { at } 3.5<S<7.5 p p t \\
0 & \text { at } S \leq 3.5 p p t
\end{aligned}\right.
$$

where $F R s$ is salinity modified filtration rate, $S$ is the ambient salinity in ppt.

(3) Filtration rate and turbidity

Salinity-based filtration rate is then modified by turbidity:

$$
F R_{\tau}=F R_{S}\left[1-0.01\left(\frac{\left.\log _{10}(\tau)+3.38\right)}{0.0418}\right)\right]
$$

where $\tau$ is turbidity (or total particulate content) $\left(\mathrm{g}^{-1}\right)$. 
(4) Population density and flow velocity on food reduction

The effect of oyster density on food availability is determined following Klinck et al. (1992):

$$
f=\frac{k}{\left(k / f_{0}-1\right) e^{-r d}+1}
$$

where $f$ is the fractional reduction in food, $d$ is oyster density $\left(\mathrm{cal} \mathrm{m}^{-2}\right), f_{0}$ is density on food reduction factor, obtained from model calibration, $k$ and $r$ represent current velocity related food reduction factors, if velocity $\left(\mathrm{cm} \mathrm{s}^{-1}\right)$ is larger than the threshold on food reduction, $k=0.31$ and $r=1.136 \times 10^{-6}$; otherwise, $k=0, r=1$, or no food reduction assumed given the enhanced food supply with increased flow current velocity up to the threshold.

(5) Ingestion and assimilation

Oyster food ingestion is the product of food availability and filtration rate.

$$
I=(1-f) F C F R_{\tau}
$$

where $I$ is ingestion ( $\mathrm{g} \mathrm{AFDW} \mathrm{wk}^{-1}$ ) and $F C$ is food concentration $\left(\mathrm{mg} \mathrm{l}^{-1}\right)$.

$$
\mathrm{A}=\mathrm{I} A_{e f f}
$$

where $A$ is assimilation ( $\mathrm{g}$ AFDW $\left.\mathrm{wk}^{-1}\right), A_{\text {eff }}$ is the assimilation efficiency $(=0.75$, Table 1$)$.

(6) Respiration

Oyster respiration is a function of temperature and oyster weight:

$$
R=(69.7+12.6 T) W^{(b-1)}
$$

where $R$ is respiration ( $\mu 1 \mathrm{O}_{2}$ consumed $\mathrm{hr}^{-1} \mathrm{~g} \mathrm{AFDW}^{-1}$ ), W is weight (g AFDW), obtained from the length-weight relationship (Eq. 1), and $b=0.75$.

Salinity effect on respiration is determined by following:

$$
\begin{aligned}
& R_{r}=\left\{\begin{array}{l}
0.007 T+2.099 \text { at } T<20{ }^{\circ} \mathrm{C} \\
0.0915 T+1.324 \text { at } T \geq 20{ }^{\circ} \mathrm{C}
\end{array}\right. \\
& R_{S}=\left\{\begin{array}{c}
R \text { at } S \geq 15 p p t \\
R\left(1+\left[\frac{(15-S)\left(R_{r}-1\right)}{5}\right] \text { at } 10<S<15 p p t\right. \\
R R_{r} \text { at } S \leq 10 p p t
\end{array}\right.
\end{aligned}
$$

where $\mathrm{Rr}$ is a ration of respiration at $10 \mathrm{ppt}$ to respiration at $20 \mathrm{ppt}$, Rs is salinitymodified respiration.

(7) Reproduction 
The portion of net production going into reproduction $\left(P_{r}\right)$ is given by following:

$$
\begin{aligned}
& P_{r}=R_{e f f} \mathrm{NP} \\
& R_{e f f}=0.054 \mathrm{~T}-0.729 \text { (January - June) } \\
& R_{e f f}=0.047 \mathrm{~T}-0.809 \text { (July - December) }
\end{aligned}
$$

where $R_{\text {eff }}$ is reproduction efficiency, maximum $R_{\text {eff }}$ is set to 0.7 (Table 1 ).

(8) Spawning

Spawning occurs when the cumulative reproductive biomass exceeds $20 \%$ of total biomass. Once spawning occurs, the total reproductive biomass was apportioned into male and female biomass. The ratio of females to males $\left(f_{\text {ratio }}\right)$ is calculated by:

$$
f_{\text {ratio }}=0.021 L_{b}-0.62
$$

where $L b$ is shell length in $\mathrm{mm}$. Then, the female portion of reproductive biomass $\left(P_{r f}\right)$ can be calculated and converted into eggs spawned by:

$$
\begin{aligned}
& N_{\text {egg }}=P_{r f}\left(\frac{1}{6133}\right)\left(\frac{1}{W_{\text {egg }}}\right) \\
& W_{\text {egg }}=2.14 \times 10^{-14} V_{\text {egg }}
\end{aligned}
$$

where Negg, Wegg, and Vegg are the number of oyster egg spawned, egg weight $\left(10^{-9} \mathrm{~g}\right.$ AFDW), and egg volume $\left(\mu \mathrm{m}^{3}\right)$, respectively.

(9) Larval recruitment

Larval life span was set at 18 days and larval to spat survival was set at $1 / 10^{8}$.

(10) Mortality

For larvae:

$$
N_{\text {rlar }}=M_{\text {lar }} N_{\text {egg }}
$$

where $N_{\text {rlar }}$ is number of larvae recruited per spawn, $M_{\text {lar }}$, is the larval mortality rate (per spawn $=80 \%$ when temperature: $27.5-32.5^{\circ} \mathrm{C}$, and salinity 10-27.5 ppt, otherwise, mortality $=100 \%$.

For post-settlement population:

Number of dying per week $=M_{w k}$ (number of living oysters) where $M_{w k}$ is the daily mortality rate $\left(\mathrm{wk}^{-1}\right)$, derived from the mean mortality as a function of annual mean salinity and temperature (Eq. 2). 
The important Caloric conversions used in the model include: $6100 \mathrm{cal} \mathrm{g}^{-1}$ dry wt for

Oysters; $5168 \mathrm{cal} \mathrm{g}^{-1}$ dry wt for food; and $6133 \mathrm{cal} \mathrm{g}^{-1}$ dry wt for oyster eggs.

\section{References}

Allison, M.A., Meselhe, E.A., 2010. The use of large water and sediment diversions in the lower Mississippi River (Louisiana) for coastal restoration. J. Hydrol. 387(34), 346-360.

Banks, P.D., 2011. Comprehensive report of the 2010 Oyster mortality study in Breton Sound and Barataria Basins. LDWF Fisheries Division.

Cable, J.E., Swenson, E.M., Snedden, G.A., Swarzenski, C., 2007. Surface Water Hydrology in Upper Breton Sound Basin, Louisiana: Effects of the Caernarvon Freshwater Diversion. Final report. Coastal Restoration Division. Louisiana Department of Natural Resources, 149 pp.

Chatry, M., Dugas, R.J., Easley, K.A., 1983. Optimum salinity regime for oyster production on Louisiana's state seed grounds. Contrib. Mar. Sci. 26, 81-94.

Chen, Q., Zhao, H., Hu, K., Twilley, R. R., Cable, J. E., 2010. An integrated storm surge, hurricane waves, salinity and sediment transport modeling system for Breton Sound, LA. NGI Annual Conference, Mobile, AL. May 18-20.

Coastal Protection and Restoration Authority (CPRA), 2012. Louisiana's Comprehensive Master Plan for a Sustainable Coast. State of Louisiana. http://coastal.la.gov/acommon-vision/2012-coastal-master-plan/.

Coen, L.D., Luckenbach, M.W., 2000. Developing success criteria and goals for evaluating oyster reef restoration: ecological function or resource exploitation? Ecol. Eng. 15, 323-343.

Couvillion, B.R., Steyer, G.D., Wang, H., Beck, H.J., Rybczyk, J., 2013. Forecasting the effects of coastal protection and restoration projects on wetland morphology in coastal Louisiana under multiple environmental uncertainty scenarios. J. Coast. Res. SI (67), 29-50.

Day, J.W., Ko, J., Cable, J., Day, J.N., Fry, B., Hyfield, E., Kemp, P., Lane, R., Mashriqui, H., Reyes, E., Rick, S., Snedden, G., Swenson, E., Templet, P., 
Twilley, R., Wissel, B., 2003. Pulses: The Importance of Pulsed Physical Events for Louisiana Floodplains and Watershed Management. In: K.G. Renard, S.A. McElroy, W.J. Gburek, H.E. Canfield, R.L. Scott, editors. First Interagency Conference on Research in the Watersheds. U.S. Department of Agriculture, Agricultural Research Service, Washington, DC, October 27-30, 2003. pp. 693699.

Day, J.W., Cable, J.E., Cowan, J.H., Delaune, R., Mutsert, K.D., Fry, B., Mashriqui, H., Justic, D., 2009. The Impacts of Pulsed Reintroduction of River Water on a Mississippi Delta Coastal Basin. J. Coast. Res. 54, 225-243.

Day, J.W., Lane, R., Moerschbaecher, M., DeLaune, R., Mendelssohn, I., Baustian, J., Twilley, R., 2013. Vegetation and soil dynamics of a Louisiana estuary receiving pulsed Mississippi River water following Hurricane Katrina. Estuaries Coasts 36, 665-682.

Dame, R.F., 1972. The ecological energies of growth, respiration, and assimilation in the intertidal American oyster Crassostrea virginica. Mar. Biol. 17, 243-250.

DeLaune, R.D., White, J.R., 2012. Will coastal wetlands continue to sequester carbon in response to an increase in global sea level?: a case study of the rapidly subsiding Mississippi River deltaic plain. Clim. Change 110, 297-314.

Deltares, 2013. D-Water Quality User Manual. Delft, the Netherlands, 414pp.

Dekshenieks, M.M., Hofmann, E.E., Klinck, J.M., Powell, E.N., 2000. Quantifying the effects of environmental change on an oyster population: a modeling study. Estuaries 23, 593-610.

DeMarco, K., Mouton, J., Pahl, J.W., 2012. Recommendations for anticipating sea-level rise impacts on Louisiana coastal resources during project planning and design: Summary of the technical report for coastal managers. Coastal Protection and Restoration Authority of Louisiana, January 24, 2012.

Driessen, T.L.A., Ledden, M.V., 2013. The large-scale impact of climate change to Mississippi flood hazard in New Orleans. Drink. Water Eng. Sci. 6, 81-87.

Galtsoff, P.S., 1964. The American oyster Crassostrea virginica Gmelin. Fish. Bull. Fish Wildl. Serv. US 64, 1-80. 
Grizzle, R.E., Lnagdon, R., Howell, W.H., 1992. Growth responses of suspensionfeeding bivalve molluscs to changes in water flow: differences between siphonate and non-siphonate taxa. J. Exp. Mar. Biol. Ecol. 162, 213-228.

Hilton, T.W., Najjar, R.G., Zhong, L., Li, M., 2008. Is there a signal of sea-level rise in Chesapeake Bay salinity? J. Geophys. Res. 113, 1-12.

Hofmann, E.E., Powell, E.N., Klinck, J.M., Wilson, E.A., 1992. Modeling oyster populations. III. Critical feeding periods, growth and reproduction. J. Shell. Res. 11 (2), 399-416.

Hofmann, E.E., Klinck, J.M., Powell, E.N., Boyles, S., Ellis, M., 1994. Modeling oyster populations. II. Adult size and reproductive effort. J. Shell. Res. 13 (1), 165-182.

Hu, K., Chen, Q., Wang, H., 2015. A numerical study of vegetation impact on reducing storm surge by wetlands in a semi-enclosed estuary. Coast. Eng. 95, 66-76.

Huang, H., Justic, D., Lane, R., Day, J., Cable, J., 2011. Hydrodynamic response of the Breton Sound estuary to pulsed Mississippi River inputs. Estuar. Coast. Shelf Sci. 95, 216-231.

Huang, W., Hagen, S., Bacopoulos, P., Wang, D., 2015. Hydrodynamic modeling and analysis of sea-level rise impacts on salinity for oyster growth in Apalachicola Bay, Florida. Estuar. Coast. Shelf Sci. 156, 7-18.

Klinck, J.M., Powell, E.N., Hofmann, E.E., Wilson, E.A., Ray, S.M., 1992. Modeling oyster populations: the effect of density and food supply on production. Pro. Adv. Mar. Tech. Conf. 5, 85-105.

Klinck, J.M., Hofmann, E.E., Powell, E.N., Dekshenieks, M.M., 2002. Impact of channelization on oyster production: a hydrodynamic-oyster population model for Galveston Bay, TX. Environ. Mod. Assess. 7, 273-289.

La Peyre, M. K., Nickens, A. D., Volety, A. K., Tolley, G. S., La Peyre, J. F., 2003. Environmental significance of freshets in reducing Perkinsus marinus infection in eastern oysters Crassostrea virginica: potential management applications. Mar. Ecol. Prog. Ser. 248, 165-176.

La Peyre, M.K., Gossman, B., LaPeyre, J.F., 2009. Defining Optimal Freshwater Flow for Oyster Production: Effects of Freshet Rate and Magnitude of Change and 
Duration on Eastern Oysters and Perkinsus marinus Infection. Estuaries Coasts $32,522-534$.

La Peyre, M.K., Casas, S.M., Gayle, W., LaPeyre, J.F., 2010. The combined influence of sub-optimal temperature and salinity on the in vitro viability of Perkinsus marinus, a protistan parasite of the eastern oyster Crassostrea virginica. J. Invertebr. Pathol. 105, 176-181.

La Peyre, M.K., Eberline, B.S., Soniat, T.M., La Peyre, J.F., 2013. Differences in extreme low salinity timing and duration differentially affect eastern oyster (Crassostrea virginica) size class growth and mortality in Breton Sound, LA. Estuar. Coast. Shelf Sci. 135, 146-157.

La Peyre, M.K., Humphries, A.T., Casas, S.M., La Peyre, J. F., 2014. Temporal variation in development of ecosystem services from oyster reef restoration. Ecol. Eng. 63, 34-44.

La Peyre, M.K., Geaghan, J., Decossas, G., La Peyre, J., 2016. Analysis of environmental factors influencing salinity patterns, oyster growth and mortality in lower Breton Sound Estuary, Louisiana using 20 years of data. J. Coast. Res. 32, 519-530.

Lane, R.R., Day Jr., J. W., Marx, B.D., Reyes, E., Hyfield, E., Day, J.N., 2007. The effects of riverine discharge on temperature, salinity, suspended sediment and chlorophyll a in a Mississippi delta estuary measured using a flow-through system. Estuar. Coast. Shelf Sci. 74, 145-154.

Lenihan, H.S., Peterson, C.H., Allen, J.M., 1996. Does flow speed also have a direct effect on growth of active suspension feeders: an experimental test on oysters Crassostrea virginica (Gmelin). Limnol. Oceanogr. 41, 1359-1366.

Leonhardt, J.M., Casas, S., Supan, J.E., La Peyre, J.F., 2017. Stock Assessment for eastern oyster seed production and field grow-out in Louisiana. Aquaculture 466, 9-19.

Livingston, R.J., Lewis, F.G., Woodsum, G.C., Niu, X.F., Galperin, B., Huang, W., Christensen, J.D., Monaco, M.E., Battista, T.A., Klein, C.J., Howell, R.L., Ray, G.L., 2000. Modeling oyster population response to variation in freshwater input. Estuar. Coast. Shelf Sci. 50, 655-672. 
Louisiana Department of Wildlife and Fisheries (LDWF), 2009. Oyster stock assessment report of the public oyster areas in Louisiana seed grounds and seed reservations. Oyster data report series. Baton Rouge, LA: Louisiana Department of Wildlife and Fisheries. 98 pp.

Lundberg, C.J., Lane, R.R., Day, Jr. J.W., 2014. Spatial and temporal variations in nutrients and water quality parameters in the Mississippi River-influenced Breton Sound estuary. J. Coast. Res. 30, 328-336.

Martyr, R.C., Dietrich, J.C., Westerink, J.J., Kerr, P.C., Dawson, C., Smith, J.M., Pourtaheri, H., Powell, N., Van Ledden, M., Tanaka, S., Roverts, H.J., Westerink, H.J., Westerink, L.G., 2013. Simulating hurricane storm surge in the lower Mississippi River under varying flow conditions. J. Hydraul. Eng. 139, 492-501.

Maxwell, V.J., Supan, J.E., 2010. Economic analysis of off-bottom oyster culture for triploid eastern oyster, Crassostrea virginica, culture in Louisiana. World Aquacult. Mag. 41(1), 9-14.

Meselhe, E.A., Georgiou, I., Allison, M.A., McCorquodale, J.A., 2012. Numerical modeling of hydrodynamics and sediment transport in lower Mississippi at a proposed delta building diversion. J. Hydrol. (472-473), 340-354.

Meselhe, E.A., Sadid, K.M., Allison, M.A., 2016. Riverside morphological response to pulsed sediment diversions. Geomorphology 270, 184-202.

Petes, L.E., Brown, A.J., Knight, C.R., 2012. Impacts of upstream drought and water withdrawals on the health and survival of downstream estuarine oyster populations. Ecol. Evol. 2(7), 1712-1724.

Peyronnin, N.S., Green, M., Richards, C.P., Owens, A., Reed, D., Groves, D., Chamberlain, J., Rhinehart, K., Belhadjali, K., 2013. Louisiana's 2012 Coastal Master Plan: Overview of a science-based and publicly-informed decision making process. J. Coast. Res. SI (67), 1-15.

Pfeffer, W.T., Harper, J.T., Neel, S.O., 2008. Kinematic constrains on glacier contributions to $21^{\text {st }}$ - century sea-level rise. Science 321, 1340-1343. 
Powell, E.N., Hofmann, E.E., Klinck, J.M., Ray, S.M., 1992. Modeling oyster populations. I. A commentary on filtration rate. Is faster always better? J. Shell. Res. 11 (2), 387-398.

Powell, E.N., Klinck, J.M., Hofmann, E.E., McManus, M.A., 2003. Influence of water allocation and freshwater inflow on oyster production: a hydrodynamic-oyster population model for Galveston Bay, TX, USA. Environ. Manage. 31,100-121.

Rivera-Monroy, V.H., Branoff, B., Meselhe, E.A., McCorquodale, A., Dortch, M., Steyer, G.D., Visser, J., Wang, H., 2013. Landscape-level estimation of nitrogen loss in coastal Louisiana wetlands: potential sinks under different restoration scenarios. J. Coast. Res. SI (67), 75-87.

Rybovich, M., La Peyre, M.K., Hall, S.G., La Peyre, J.F., 2016. Increased temperatures combined with lowered salinities differentially impact oyster size class growth and mortality. J. Shellfish Res. 35 (1), 1-14.

Sable, S.E., Villarrubia, C., 2011. Analysis of Fisheries-Independent Data for Evaluation of Species Distribution Responses to the Caernarvon Freshwater Diversion. CWPPRA Revised Final Project Report, Dynamic Solutions, LLC and Office of Coastal Protection and Restoration (OCPR), available at http://lacoast.gov/reports/project/CFD_fish_revised\%20report.pdf.

Sasser, C.E., Visser, J. M., Mouton, E., Linscombe, J., 2008. Vegetation Types in Coastal Louisiana in 2007. USGS Open-File Report 2008-1224. http://pubs.usgs.gov/of/2008/1224/

Shumway, S.E., 1996. Natural environmental factors. In: V.S. Kennedy, R.I.E. Newell \& A.F. Eble, editors. The Eastern Oyster Crassostrea virginica. College Park, MD: Maryland Sea Grant College, pp. 467-513.

Snedden, G.A., Cable, J.E., Swenson, E.M., Swarzenski, C., 2007. Sediment discharge into a subsiding Louisiana deltaic estuary through a Mississippi River diversion. Estuar. Coast. Shelf Sci. 71, 181-193.

Solomon, J.A., Donnelly, M.J., Walters, L.J., 2014. Effects of sea level rise on the intertidal oyster Crassostrea virginica by field experiments. J. Coast. Res. SI (68), 57-64. 
Soniat, T. M., Powell, E.N., Hofmann, E. E., Klinck, J.M., 1998. Understanding the success and failure of oyster populations: the importance of sampled variables and sample timing. J. Shellfish Res. 17, 1149-1165.

Soniat, T.M., Cozelmann, C.P., Byrd, J.D., Roszell, D.P., Bridevaux, J. L., Suir, K.J., Colley, S.B., 2013. Predicting the effects of proposed Mississippi River diversions on oyster habitat quality: Application of an oyster habitat suitability index model. J. Shellfish. Res. 32 (3), 629-638.

U.S. Army Corps of Engineers, 1984. Louisiana coastal area, Louisiana freshwater diversion to Barataria and Breton Sound Basins. Feasibility Study and EIS, New Orleans District.

Walton, W.C., Davis, J.E., Supan, J.E., 2013. Off-bottom culture of oysters in the Gulf of Mexico. Southern Regional Aquaculture Center, SRAC Pub. No. 4308. 6 pp.

Wang, H., Huang, W., Harwell, M. A., Edmiston, L., Johnson, E., Hsieh, P., Milla, K., Christensen, J., Stewart, J., Liu, X., 2008. Modeling oyster growth rate by coupling oyster population and hydrodynamic models for Apalachicola Bay, Florida, USA. Ecol. Model. 211, 77-89.

Wang, H., Meselhe, E.A., Waldon, M.G., Harwell, M.C., Chen, C., 2012. Compartmentbased hydrodynamic and water quality modeling of a Northern Everglades Wetland, Florida, USA. Ecol. Model. 247 (12), 273-285.

Wang, H., Steyer, G.D., Couvillion, B.R., Rybczyk, J.M., Beck, H.J., Sleavin, W.J., Meselhe, E.A., Allison, M.A., Boustany, R.G., Fischenich, C.J., Rivera-Monroy, V.H., 2014. Forecasting landscape effects of Mississippi River diversions on elevation and accretion in Louisiana deltaic wetlands under future environmental uncertainty scenarios. Estuar. Coast. Shelf Sci. 138, 57-68.

Wang, H., Chen, Q., Hu, K., La Peyre, M.K., 2016. A modeling study of the impacts of Mississippi River diversion and sea-level rise on water quality of a deltaic estuary. Estuaries Coasts. Online Early, p. 1-27, DOI: 10.1007/s12237-016-01977.

Williams, S.J., 2013. Sea-level rise implications for coastal regions. J. Coast. Res. SI (63), 184-196. 
Table 1. Parameters used in the oyster population model.

\begin{tabular}{|c|c|}
\hline Parameter & Value \\
\hline Assimilation efficiency & 0.75 \\
\hline Maximum reproduction efficiency & 0.7 \\
\hline Larval to spat survival rate & 0.00000001 \\
\hline Larvae mortality & 0.8 \\
\hline $\begin{array}{l}\text { Fraction of cumulative reproductive biomass to total } \\
\text { biomass for spawning }{ }^{\text {a }}\end{array}$ & 0.2 \\
\hline Velocity on food reduction threshold $(\mathrm{cm} / \mathrm{s})^{b}$ & 10 \\
\hline Population density on food reduction factor & 0.155 \\
\hline
\end{tabular}

Note: a, Powell et al., 1992; b, Lenihan et al., 1996; other parameters are obtained via calibration. 
Table 2. Relative Sensitivity Index (RSI) of the BSE oyster model to model parameters.

\begin{tabular}{lccc}
\hline \multicolumn{1}{c}{ Parameter } & Total & Seed & Sack \\
\hline Assimilation efficiency & & & \\
& -509.74 & -381.20 & -854.91 \\
Maximum reproduction efficiency & 61.58 & 76.62 & 21.37 \\
& & & \\
Larval to spat survival rate & -3.75 & -1.96 & -8.43 \\
& & & \\
Larvae mortality & 15.34 & 9.13 & 32.11 \\
Fraction of cumulative reproductive biomass & & & \\
to total biomass for spawning & 1.39 & 2.09 & -0.38 \\
& & & \\
Velocity on food reduction threshold (cm/s) & -10.82 & -17.04 & 5.82 \\
& & & \\
Population density on food reduction factor & 44.32 & 3.67 & 153.48 \\
\hline
\end{tabular}


Table 3. Descriptive statistics of simulated oyster growth rates and production under diversion and SLR scenarios in Breton Sound Estuary, Louisiana.

\begin{tabular}{|c|c|c|c|c|c|c|c|c|}
\hline \multirow[b]{2}{*}{ Scenarios } & \multicolumn{4}{|c|}{$\begin{array}{c}\text { Growth Rate } \\
\text { (mg AFDW oyster }{ }^{-1} \text { wk }^{-1)}\end{array}$} & \multicolumn{4}{|c|}{$\begin{array}{c}\text { Production } \\
\left(\text { g AFDW } \mathrm{m}^{-2} \mathrm{yr}^{-1}\right)\end{array}$} \\
\hline & Mean & Min & Max & SD & Mean & Min & Max & SD \\
\hline Baseline Year & 4.10 & -3.30 & 22.58 & 3.15 & 303 & 124 & 2747 & 150 \\
\hline Diversion $142 \mathrm{~m}^{3} \mathrm{~s}^{-1}$ & 3.33 & -4.30 & 18.98 & 2.92 & 287 & 117 & 2096 & 138 \\
\hline Diversion $7080 \mathrm{~m}^{3} \mathrm{~s}^{-1}$ & -1.04 & -6.95 & 13.80 & 2.59 & 121 & 46 & 1019 & 100 \\
\hline SLR $0.38 \mathrm{~m}$ & 2.68 & -3.82 & 31.35 & 2.92 & 254 & 116 & 1292 & 114 \\
\hline SLR $1.44 \mathrm{~m}$ & 0.82 & -5.08 & 16.62 & 3.45 & 192 & 77 & 823 & 92 \\
\hline $\begin{array}{l}\text { SLR } 0.38 \mathrm{~m}+ \\
\text { Diversion } 142 \mathrm{~m}^{3} \mathrm{~s}^{-1}\end{array}$ & 1.90 & -4.39 & 26.96 & 3.13 & 220 & 95 & 1020 & 107 \\
\hline $\begin{array}{l}\text { SLR } 0.38 \mathrm{~m}+ \\
\text { Diversion } 7080 \mathrm{~m}^{3} \mathrm{~s}^{-1}\end{array}$ & -1.01 & -6.20 & 12.61 & 2.33 & 113 & 60 & 646 & 62 \\
\hline $\begin{array}{l}\text { SLR } 1.44 \mathrm{~m}+ \\
\text { Diversion } 142 \mathrm{~m}^{3} \mathrm{~s}^{-1}\end{array}$ & 1.07 & -4.87 & 16.61 & 3.51 & 202 & 83 & 793 & 92 \\
\hline $\begin{array}{l}\text { SLR } 1.44 \mathrm{~m}+ \\
\text { Diversion } 7080 \mathrm{~m}^{3} \mathrm{~s}^{-1}\end{array}$ & -1.77 & -6.30 & 8.66 & 2.32 & 108 & 58 & 575 & 44 \\
\hline
\end{tabular}




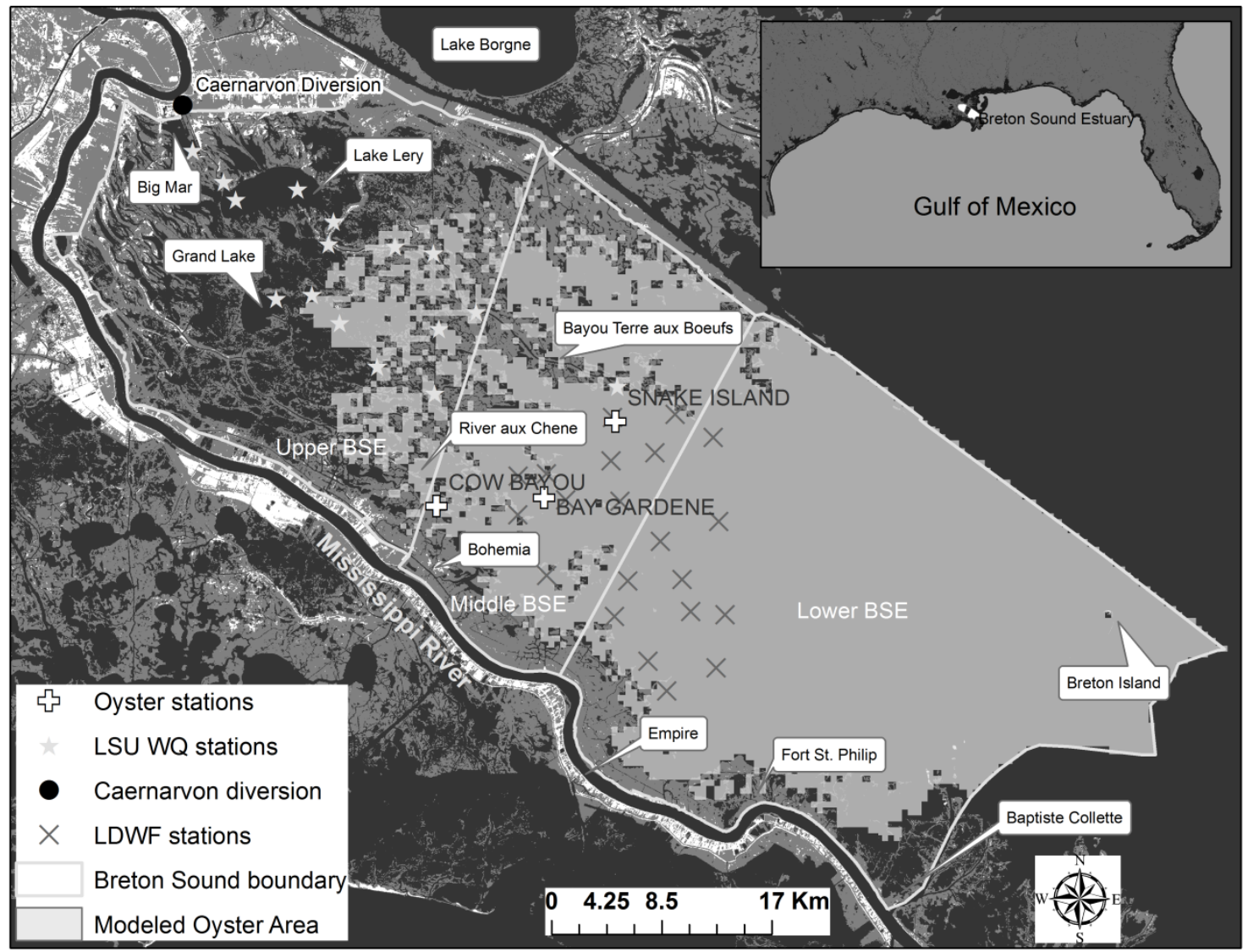

Figure 1. Map of modeled oyster areas based on distributions of seed ground, lease lines, and oyster reefs, and locations of the three oyster stations (Cow Bayou, Bay Gardene, and Snake Island) for oyster model calibration and validation as well as LDWF and LSU monitoring stations in Breton Sound Estuary, Louisiana. 


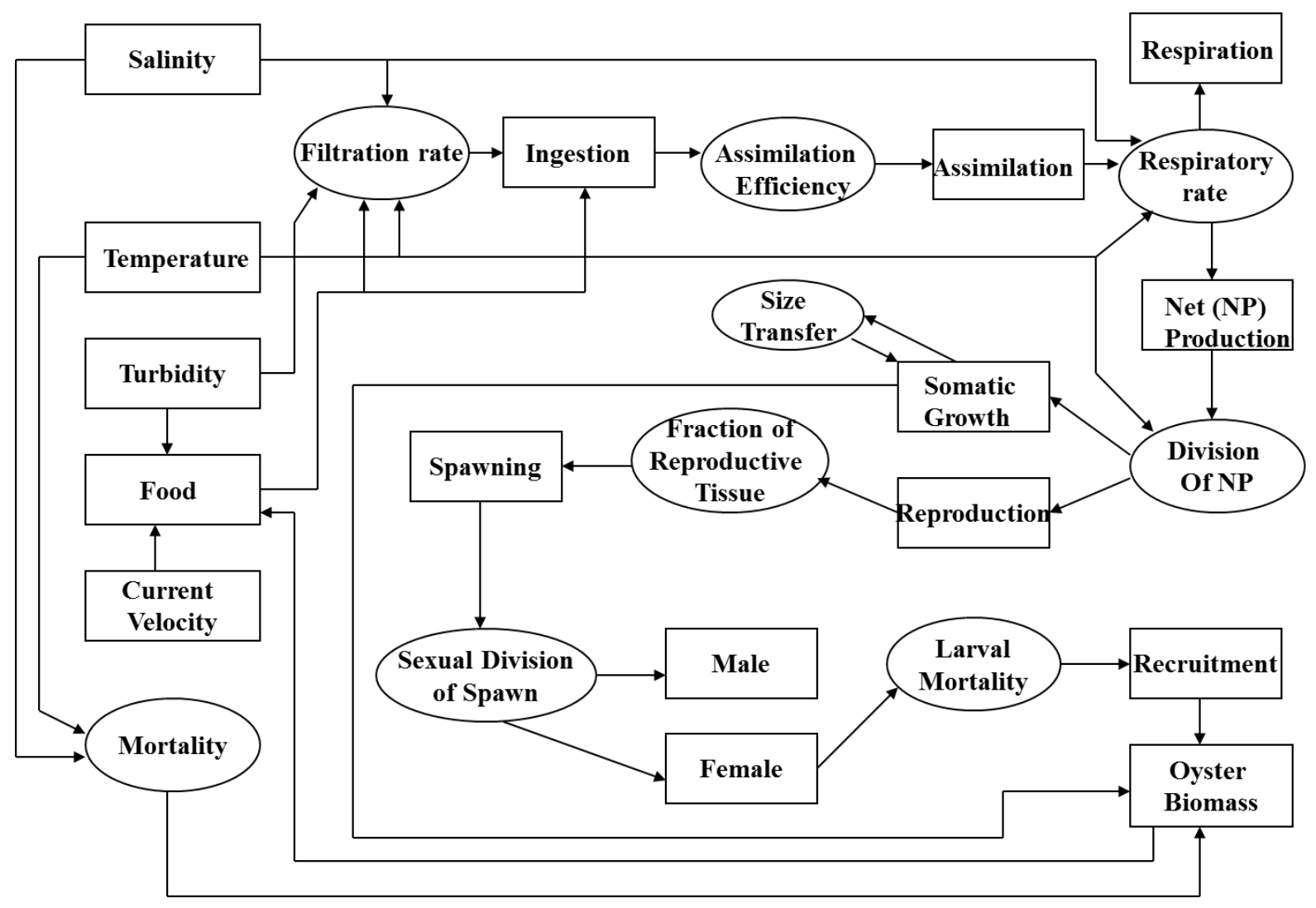

Figure 2. Flow diagram of the relationships among oyster population dynamics and influencing environmental factors that are built in the coupled hydrodynamic-water quality-oyster model (Modified from Wang et al., 2008). 


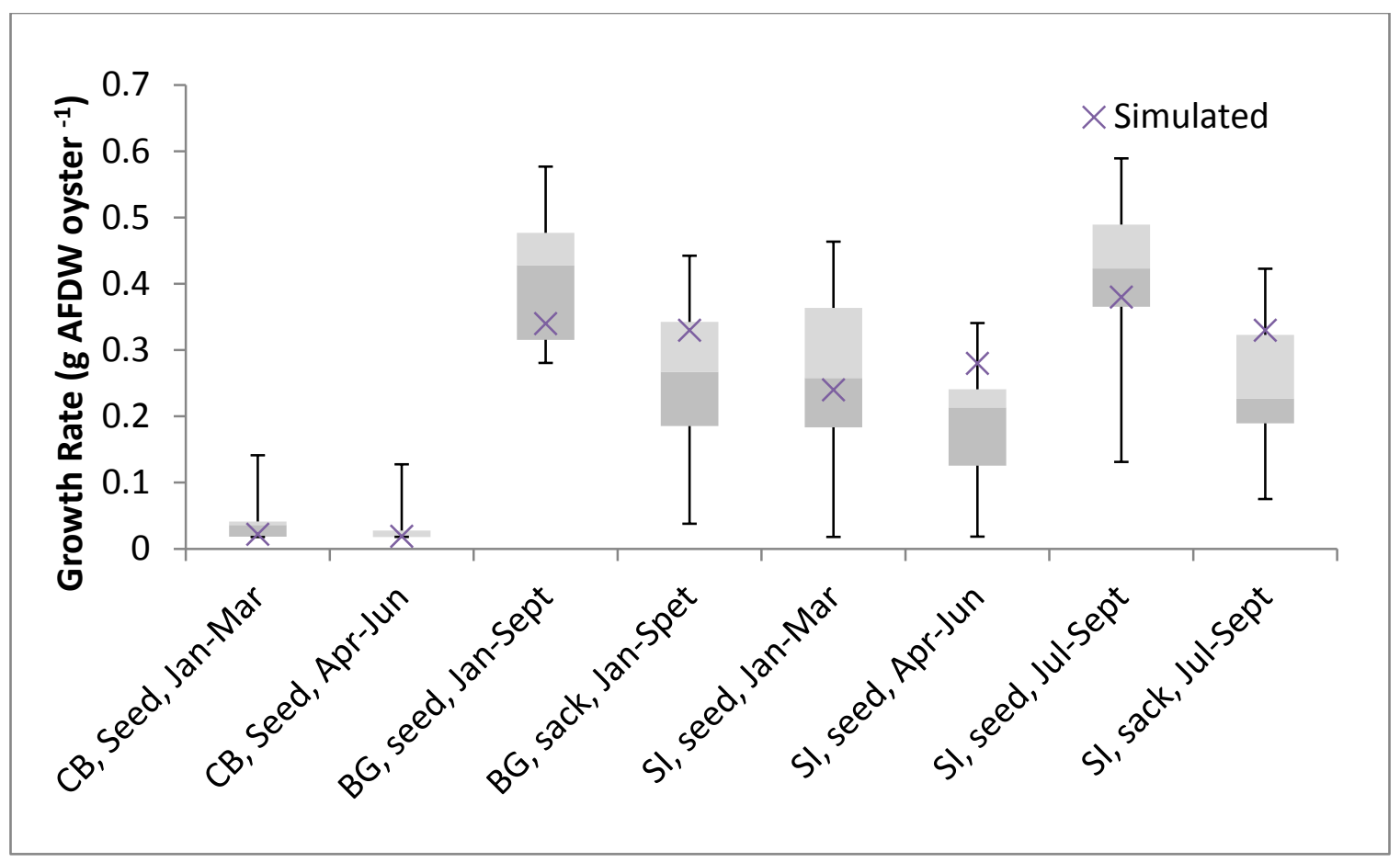

Figure 3. Oyster model calibration results using observed quarterly growth data for seed and sack oysters (source: LDWF) at Cow Bayou (CB) and Snake Island (SI) and growth rates during January to September at Bay Gardene (BG) in 2009. The error bars represent maximum and minimum observed growth rates. 


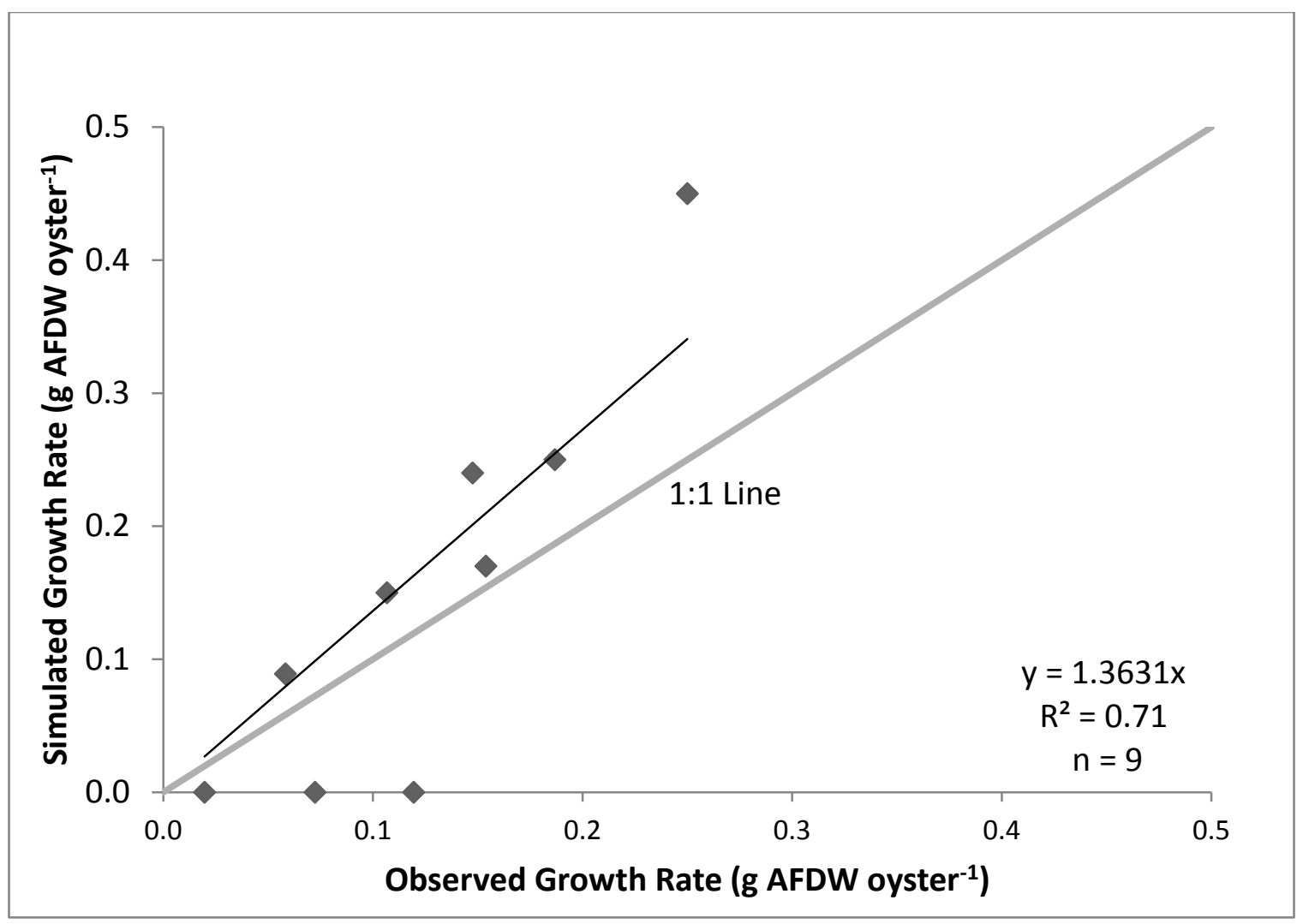

Figure 4. Oyster model validation results using observed bi-monthly growth data for seed and sack oysters (source: Eberline, 2012) at Cow Bayou, Bay Gardene, and Snake Island in 2011. 


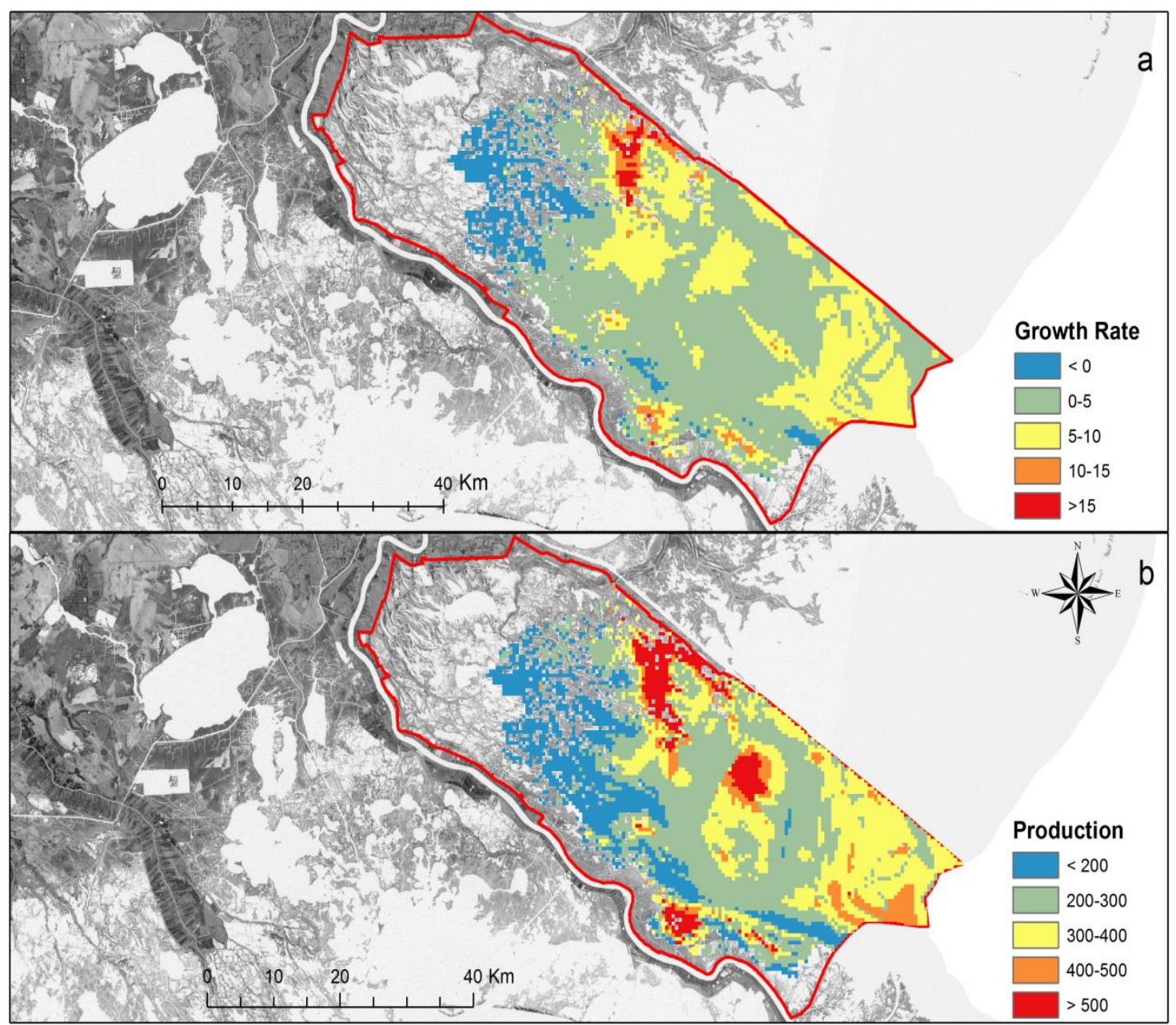

Figure 5. The distributions of simulated oyster (a) growth rate (mg AFDW oyster ${ }^{-1} \mathrm{wk}^{-1}$ ), and (b) production (g AFDW m${ }^{-2} \mathrm{yr}^{-1}$ ) in baseline year 2009 in BSE, Louisiana. 


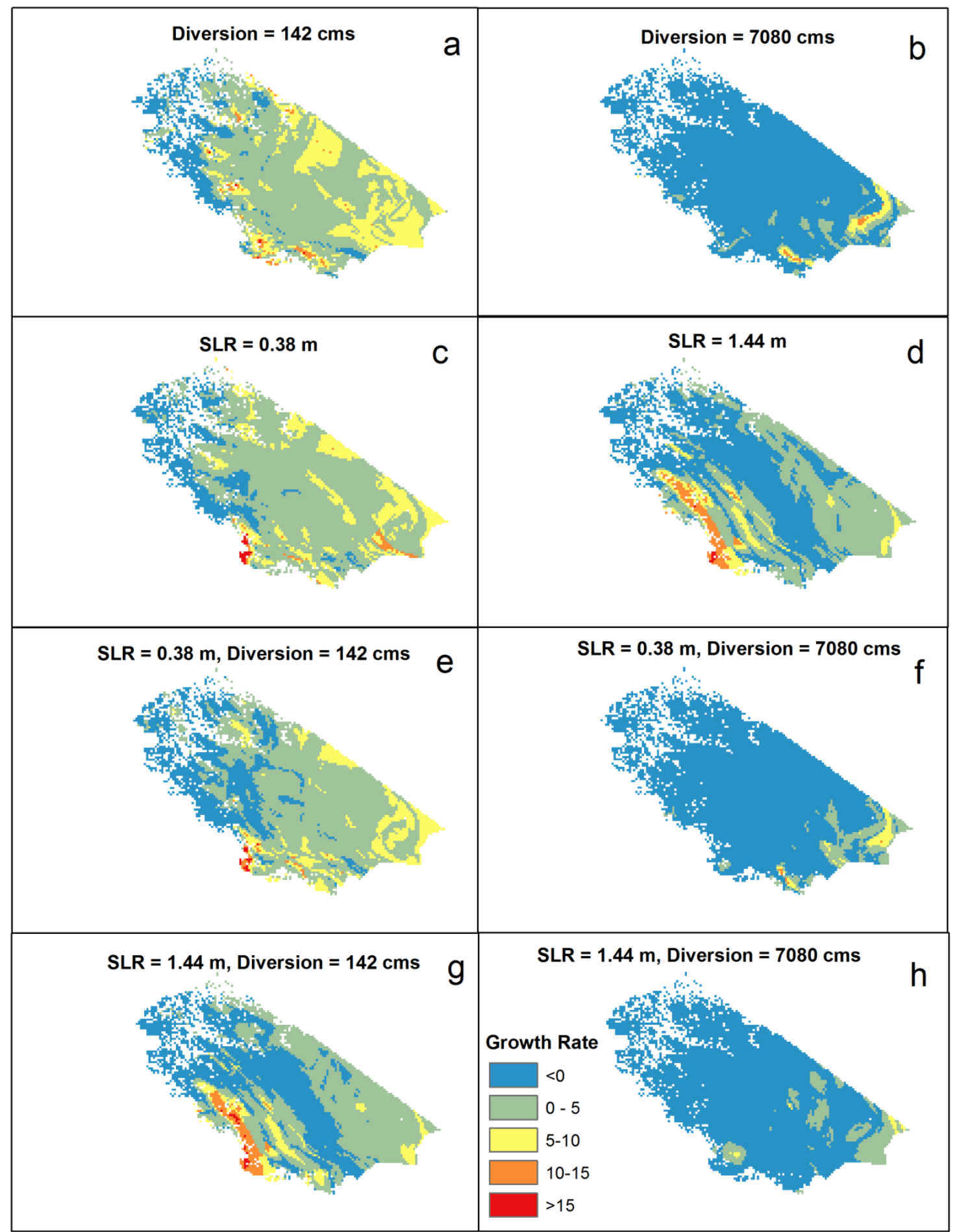

Figure 6. Spatial patterns of simulated oyster growth rates (mg AFDW oyster ${ }^{-1} \mathrm{wk}^{-1}$ ) under different Caernarvon diversion and SLR scenarios in BSE, Louisiana. Note: $\mathrm{cms}=$ $\mathrm{m}^{3} \mathrm{~s}^{-1}$. 


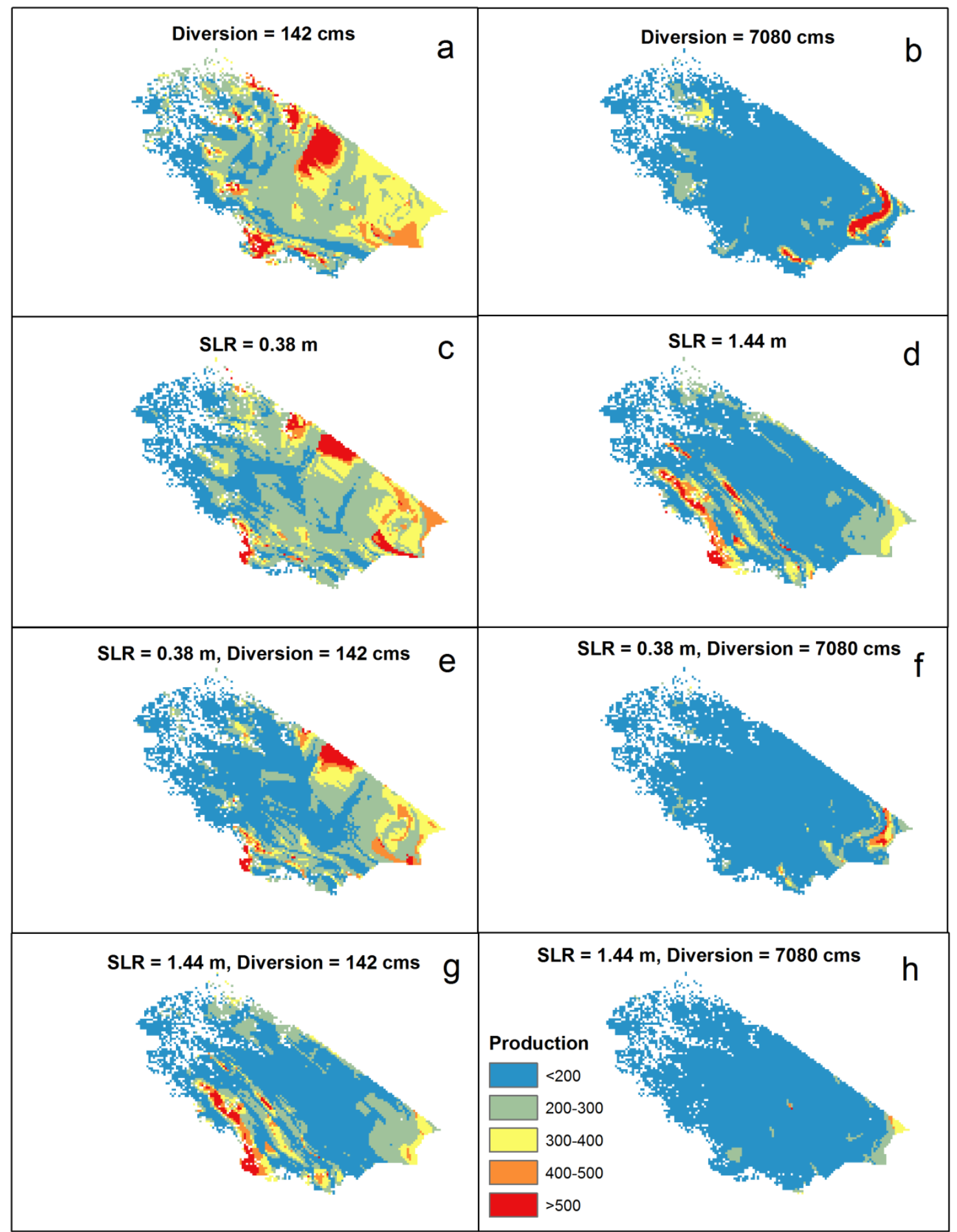

Figure 7. Spatial patterns of simulated oyster production ( $\mathrm{g}$ AFDW m $\mathrm{m}^{-2} \mathrm{yr}^{-1}$ ) under different Caernarvon diversion and SLR scenarios in BSE, Louisiana. Note: $\mathrm{cms}=\mathrm{m}^{3} \mathrm{~s}^{-1}$. 